\title{
Revisiting the Heavy Rainfall Event over Northern Taiwan on 3 June 1984
}

\author{
Chih-Ying Chen ${ }^{1}$, Yi-Leng Chen ${ }^{2}$, Ching-Sen Chen ${ }^{1, *}$, Pay-Liam Lin ${ }^{1}$, and Che-Ling Liu ${ }^{1}$ \\ ${ }^{I}$ Institute of Atmospheric Physics, National Central University, Chung-Li, Taiwan \\ ${ }^{2}$ Department of Meteorology, University of Hawaii, Honolulu, Hawaii, U. S. A.
}

Received 10 September 2012, accepted 4 July 2013

\begin{abstract}
In this study, the mechanisms for the development of a localized heavy rainfall event during the evening of 2 June to the early morning of 3 June 1984 over northern Taiwan are investigated. This event occurred under favorable large-scale conditions including: upper-level divergence; low-level high equivalent potential temperature; low levels of free convection; and subsynoptic-scale ascending motion over the northern Taiwan Strait and northern Taiwan associated with a baroclinic front. In the late night of 2 June, pre-existing rainfall is simulated to the southeast of a trough axis over the southeastern China coast as well as in the frontal zone north of Taiwan. The pre-existing rainfall is enhanced as it moves over the northeastern Taiwan Strait where the prevailing southwesterly winds within the Taiwan Strait converge with the orographically deflected flow with a southerly wind component off the western/northwestern Taiwan coast. As the pre-existing convective rainfall continues to move toward northern Taiwan, it is further enhanced in a localized low-level convergence zone over the northwestern coast where a barrier jet along the coast converges with the northwesterly winds behind the surface front. Furthermore, on the morning of 3 June, focusing of rainfall is simulated where the barrier jet encounters the leading edge of the cold pool caused by rain evaporative cooling. As the convective rainfall areas drift inland, the orographic lifting of the pre-frontal southwesterly flow over the slopes south of the Taipei Basin also plays a role in the simulated enhanced heavy rainfall there.
\end{abstract}

Key words: Mei-Yu front, Orographic effects, Heavy rainfall

Citation: Chen, C. Y., Y. L. Chen, C. S. Chen, P. L. Lin, and C. L. Liu, 2013: Revisiting the heavy rainfall event over northern Taiwan on 3 June 1984. Terr. Atmos. Ocean. Sci., 24, 999-1020, doi: 10.3319/TAO.2013.07.04.01(A)

\section{INTRODUCTION}

During the early summer rainy season (mid-May to mid-June), heavy rainfall events frequently occur over the Taiwan area (Wang et al. 1985; Chen and Chen 2003). Orographic effects are important for triggering and enhancing convection over Taiwan because of the presence of mountain slopes, including the Central Mountain Range (CMR) and Snow Mountain Range (SMR), which occupy about two-thirds of the landmass of Taiwan (Chen 2000; Wang et al. 2005; Lin 2007). In addition to favorable large-scale settings, orographic effects may play an important role for the occurrence of excessive rainfall ( $\mathrm{Li}$ et al. 1997; Chen 2000; Yeh and Chen 2002; Chen et al. 2005, 2007a, 2010a, 2010b, 2011; Wang et al. 2005). Although heavy rainfall events over northern Taiwan are not as frequent as in southwestern Taiwan (Chen et al. 2007a), some heavy rainfall events in

\footnotetext{
* Corresponding author

E-mail:tchencs@atm.ncu.edu.tw
}

northern Taiwan have produced severe damage because of the dense population (Chen 1994; Chen et al. 2007b).

On the evening of 2 June, 1984 a surface front stretched from a low-pressure center over the East China Sea passing over the ocean near the northern Taiwan coast and extending to the southeastern China coast. At the same time, an $850-\mathrm{hPa}$ weak short-wave trough was over the northern Taiwan Strait (Chiou and Liu 1985a). At 20 LST 2 June, convective cloud systems were present over the Southeast China coast (Chiou and Liu 1985a). During the period from the evening of 2 June to the early morning of 3 June, pre-existing radar echoes were observed over the northern Taiwan Strait and northwestern coast of Taiwan under the presence of a $200-\mathrm{hPa}$ trough, diffluent airflow aloft, and mid-level cold air intrusion (Chiou and Liu 1985a). More than 400 (250) mm of rainfall was recorded over the northwestern Taiwan coast (Taipei Basin) as the pre-existing rain cells moved onshore (Chiou and Liu 1985a, Fig. 12 in paper). This heavy rainfall event led to five people missing, 12 injured, and 32 casualties 
(Chiou and Liu 1985a, b). In view of the significant damage associated with this event, the Taiwan Area Mesoscale Experiment (TAMEX) was conducted during the early summer rainy season during 1984 . The purpose of TAMEX was to improve the prediction of heavy precipitation to reduce property damage and casualties (Kuo and Chen 1990).

Results from TAMEX studies have shown that an orographically induced localized low-level zone is frequently observed off the northwestern Taiwan coast due to island blocking, where the deflected strong southerly flow along the northwestern coast (e.g., barrier jet; Li and Chen 1998) converges with either the prevailing southwesterly winds (Yeh and Chen 2002, 2003) or with westerly winds behind the 850-hPa trough ( $\mathrm{Li}$ et al. 1997). Convective activity could develop or strengthen over the northwest/west coast of Taiwan (Kerns et al. 2010) if offshore convergence is coupled with upper-level divergence under favorable largescale conditions (Chen and Li 1995a; Li et al. 1997). Furthermore, the strength of the barrier jet is strongest in the early morning when the land surface is coldest (Chen and $\mathrm{Li}$ 1995b; Lin et al. 2011).

In this study, we investigate the mechanisms for the occurrences of localized heavy rainfall over northwestern Taiwan and the Taipei Basin during 2 - 3 June, 1984. Chiou and Liu (1985a) suggested that the occurrence of these heavy rainfall events is due to the interaction between the outflow associated with the inland drifting convective systems from the northwestern Taiwan Strait with the outflows from the convective systems embedded in the surface front over northern Taiwan. Due to limited data, the formation and evolution of this localized heavy rainfall event has not been discussed in detail. In this study, the European Centre for Medium-Range Weather Forecast (ECMWF) re-analysis data with 1.5 degree, satellite imagery, radar reflectivity, and rainfall data are used to study the subsynoptic and mesocale processes favorable for the development of the observed heavy precipitation. The interaction between the outflow boundary and environmental flow suggested by Chiou and Liu (1985a) is also examined. Numerical simulations using the Weather Research and Forecast model (WRF; Skamarock et al. 2005) were employed to diagnose the physical processes responsible for the occurrences of the observed localized heavy rainfall.

\section{OBSERVATIONAL ANALYSIS}

\subsection{Evolution of Weather Patterns}

At 20 LST (12 UTC) 2 June 1984, a 200-hPa mid-latitude trough extended from northeastern China southwestward toward central China (Fig. 1a). In the meantime, a south Asian high was over the northern South China Sea. A divergent area was present over the southeastern coast of
China, the Taiwan Strait and Taiwan. At the 500-hPa level, a trough extended from the Yellow Sea southwestward to southern China (Fig. 1b). At the 850 -hPa level, the ridgeline of the western Pacific high was over the Philippines (Fig. 1b). Concurrently a trough axis with windshift stretched from a low-pressure center over the East China Sea southwestward toward the southeastern China coast (Fig. 1b). South of the 850-hPa windshift line, a westerly flow prevailed with maximum equivalent potential temperature $\left(\theta_{\mathrm{e}}\right)$ over the Taiwan Strait and southeastern China coast (Fig. 1b). A surface front extended from the East China Sea to the southeastern China coast (Fig. 1c) consistent with Fig. 1 of Chiou and Liu (1985a). The Wu-Yi Mountains along the southeastern China coast retarded the western part of the surface front, similar to the cases reported by Chen and Hui $(1990,1992)$ and $\mathrm{Li}$ et al. (1997). From the $\theta_{\mathrm{e}}$ and saturated equivalent potential temperature $\left(\theta_{\mathrm{e}}{ }^{*}\right)$ profiles near the central Taiwan Strait $\left(24^{\circ} \mathrm{N}\right.$ and $\left.120^{\circ} \mathrm{E}\right)$, upstream of northern Taiwan (Fig. 2), it is apparent that the atmosphere is convectively unstable and conditionally unstable and the level of free convection (LFC) (Holton 2004) is around the 750-hPa level. At 23 LST, the surface front was still north of Taiwan (Fig. 3a).

At 02 LST 3 June, the surface low-pressure center over the East China Sea intensified (not shown). The eastern part of the surface front migrated southward slowly to the ocean east of northeastern Taiwan with northwesterly winds in the postfrontal region (Fig. 3b). The western part of the surface front moved out of the southeastern China coast and reached the northwestern Taiwan Strait (Fig. 3b). The 500-hPa trough migrated eastward toward the eastern China coast; concurrently, the 850-hPa trough axis moved to the northwestern Taiwan Strait (not shown). At the same time, the LFC lowered to the 925-hPa level (not shown).

At 05 LST, the eastern part of the surface front arrived over the northeastern Taiwan coast. The western part of the surface front reached the northern Taiwan coast as evidenced by the change in wind direction at Tanshui and Ilan (see Fig. 4 for the locations), respectively (Fig. 3c). Note that winds were still southwesterly over the Taipei Basin. At 08 LST 3 June, the 500-hPa trough reached the East China Sea (not shown). Over the northwestern (northeastern) coast of Taiwan, winds at Hsinchu and Suao (see Fig. 4 for the locations) changed to northwesterly and northeasterly, respectively (Fig. 3d), after the frontal passage.

\subsection{Diagnosis of Large-scale Vertical Motions Using ECMWF Gridded Data}

According to Trenberth (1978), the large-scale ascending motion caused by quasi-geostrophic forcing can be inferred from the advection of cyclonic vorticity by thermal winds. At 2000 LST 2 June, positive advection of the $700-\mathrm{hPa}$ vorticity associated with the trough by thermal winds was 
(a)

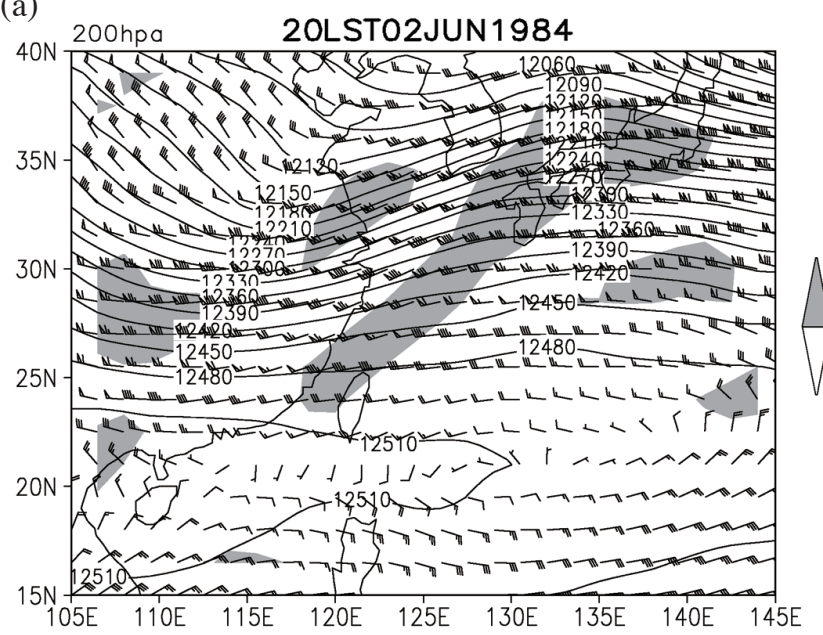

(c)

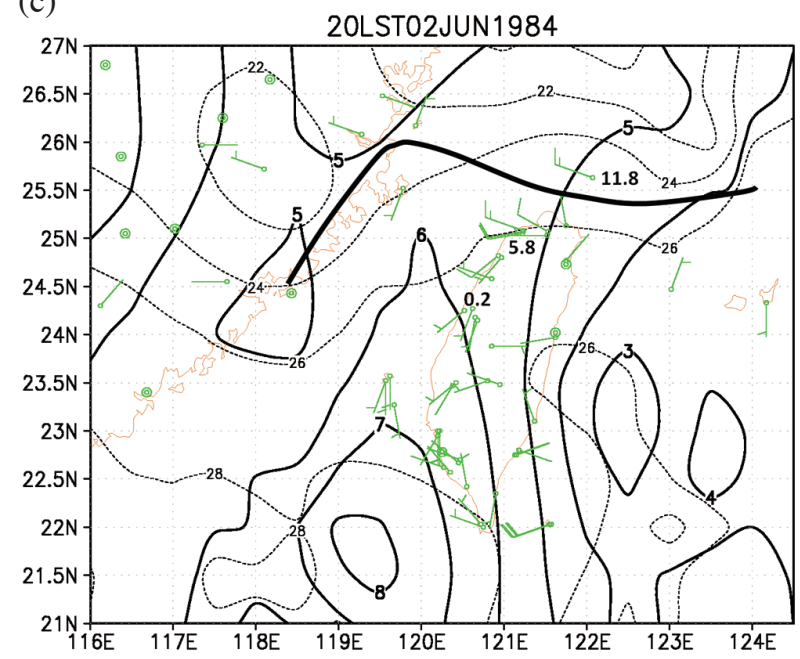

\section{OLST02JUN 1984}

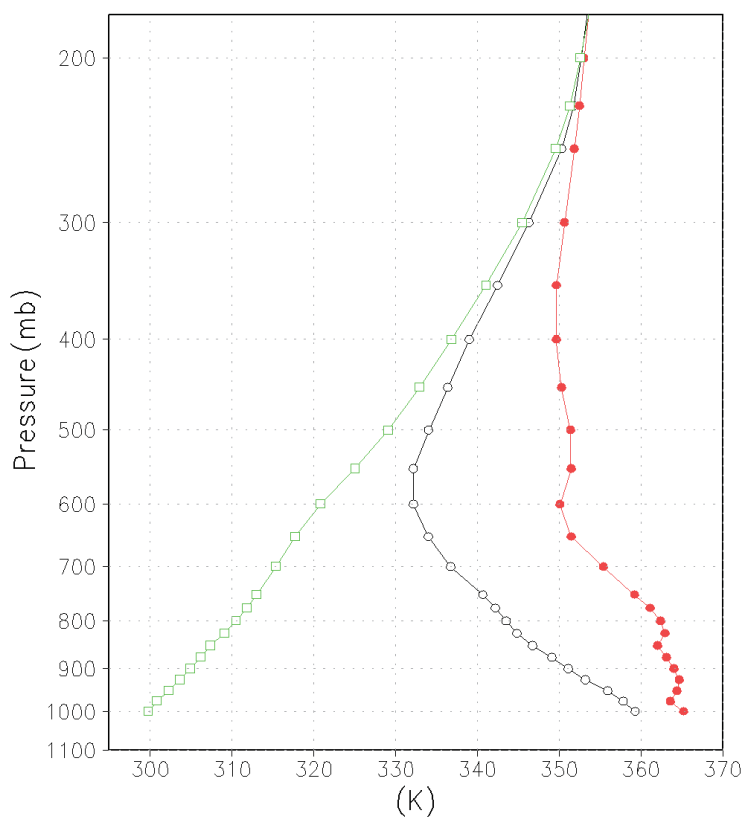

(b)

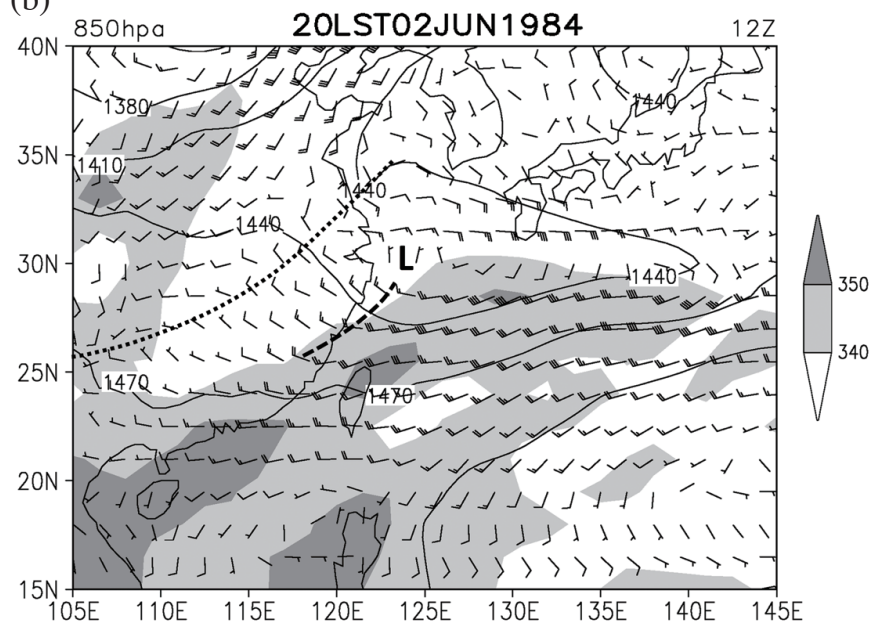

Fig. 1. (a) 200-hPa synoptic analysis at 20 LST 2 June 1984 from the ECMWF data including geopotential heights (solid lines, $30 \mathrm{gpm}$ contour interval) and winds (a full barb and a half barb represent 5 and $2.5 \mathrm{~m} \mathrm{~s}^{-1}$, respectively; also used for other figures). The grayscale represents the divergence exceeding $1 \times 10^{-5} \mathrm{~s}^{-1}$. (b) Same as (a) but for the 850 -hPa level. The contour interval for geopotential heights is $30 \mathrm{gpm}$. Dashed and dotted lines denote the approximate positions of the windshift line associated with a trough axis at the $850-\mathrm{hPa}$ level and the trough axis at the $500-\mathrm{hPa}$ level, respectively. A low pressure center is denoted by $\mathrm{L}$. The grayscale represents the equivalent potential temperature in K. (c) Regional surface map at 20 LST 2 Jun 1984 from NCEP ADP Operational Global Surface Observations. Sea level pressure (solid) every $1 \mathrm{hPa}(\mathrm{hPa}-1000)$; isotherms (dashed) every $2^{\circ} \mathrm{C}$, and winds. The heavy solid line denotes the approximate position of the surface front. The digital numbers denote the hourly rainfall rate $\left(\mathrm{mm} \mathrm{h}^{-1}\right)$ at selected conventional stations.
Fig. 2. Vertical profiles of equivalent potential temperature (open circle, K), saturated equivalent potential temperature (closed circle, $\mathrm{K}$ ), potential temperature (square, $\mathrm{K}$ ) and winds over the central Taiwan Strait at $24^{\circ} \mathrm{N}$ and $120^{\circ} \mathrm{E}$ for 2000 LST 2 June 1984 . 

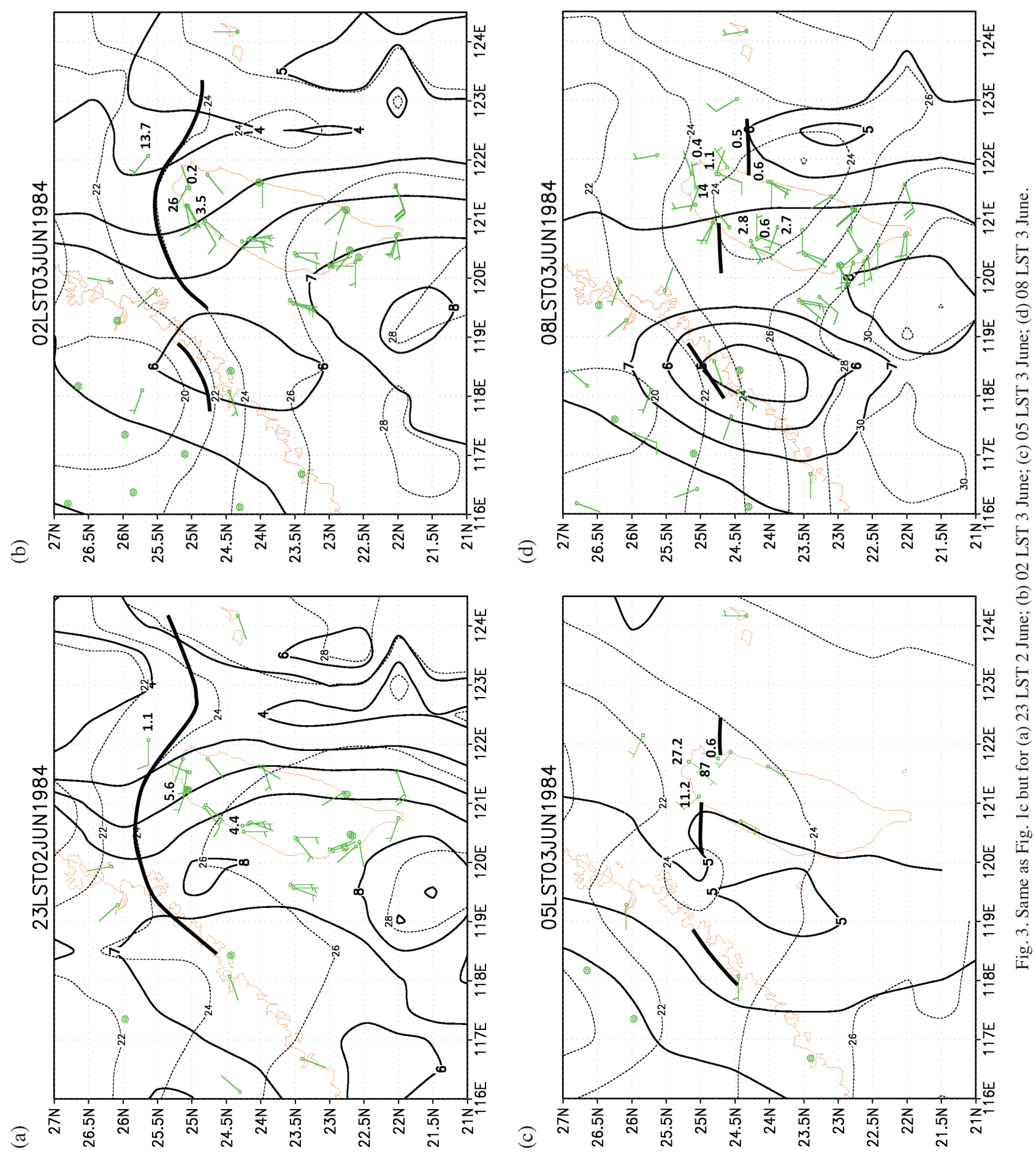


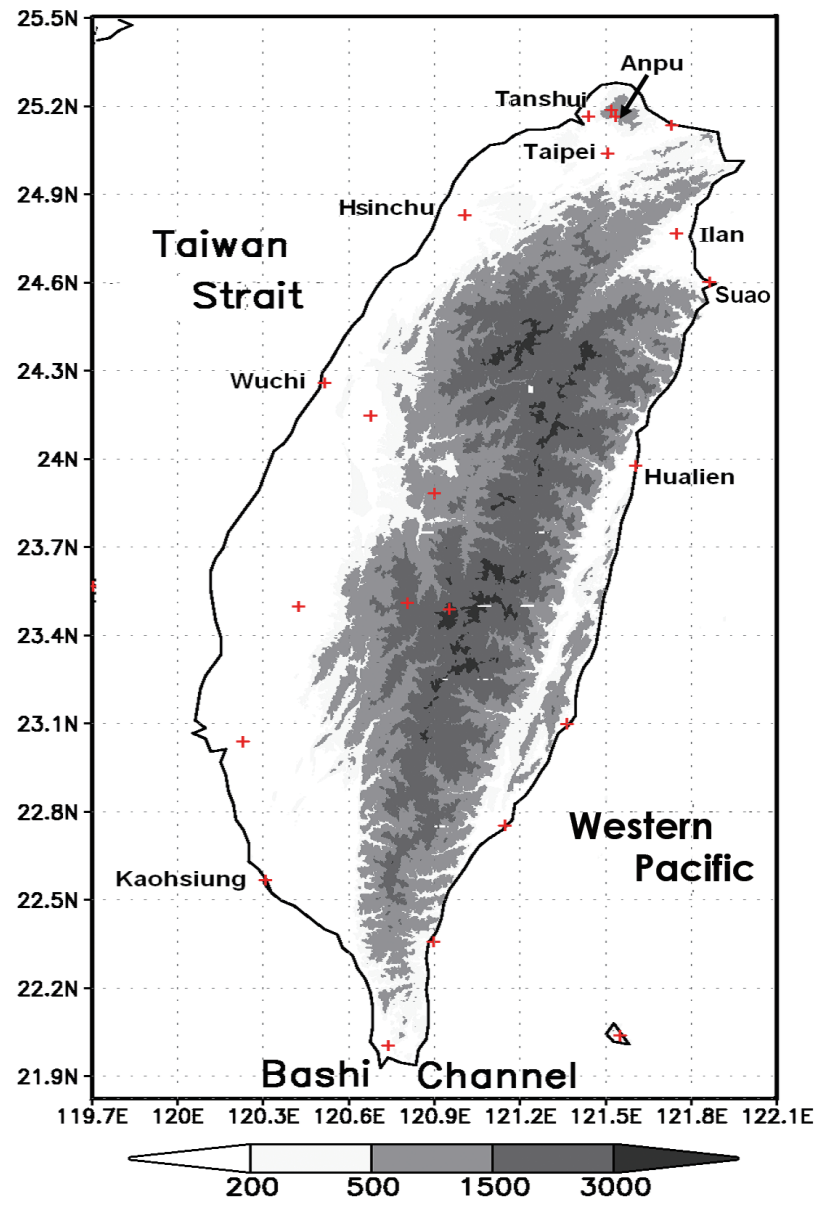

Fig. 4. Distribution of twenty-five conventional stations (crosses) in Taiwan. The grayscale shows terrain elevation in meters.

evident over the southeastern coast of China and the East China Sea (Fig. 5a), implying the presence of the rising motion there. At the $850-\mathrm{hPa}$ level, the frontogenetical forcing contributed by the horizontal deformation [Miller 1948; Eq. (7) of Chen and Li 1995a] was diagnosed along the trough axis (Fig. 1b) over the southeastern China coast and the Taiwan Strait (Fig. 5b). At the $500 \mathrm{hPa}$-level, the ascending motion was analyzed over the adjacent ocean off northern Taiwan (Fig. 5b). Similar to the surface fronts during the Taiwan Area Mesoscale Experiment (TAMEX) (Chen 1993), this frontal system possesses baroclinic characteristics.

The ascending motion associated with the surface front is favorable for the development of heavy rainfall (Chen and Li 1995a). At 20 LST 2 June, along a northwest-southeast vertical cross section (Line AB in Fig. 5b), the surface front near the southeastern China coast is characterized by significant moisture contrast, windshift, and large equivalent potential temperature gradients across the frontal zone (Figs. 6a and b). The ascending motion to the south of the surface front $\left(\approx 28^{\circ} \mathrm{N}\right)$ transported low-level moisture upward to upper levels, with relatively cold, dry air behind the surface front over southeast China (Figs. 6a and b). In ad- dition, strong low-level southwesterly winds (low-level jet, LLJ) in the prefrontal region and strong upper-level winds (upper-level jet, ULJ) on the southeastern side of the upperlevel trough associated with the jet-frontal system (Chen et al. 1994) are also evident.

At 02 LST 3 June, advection of 700-hPa vorticity by thermal winds is apparent over the northern Taiwan coast (Fig. 5c). The frontogenetical forcing contributed by horizontal deformation at the 850 -hPa level was present over the southeastern China coast, northern Taiwan Strait, and northern coast of Taiwan (Fig. 5d). At the 500-hPa level, ascending motion $\left(\approx 2 \mu \mathrm{b} \mathrm{s}^{-1}\right)$ was diagnosed over northern Taiwan (Fig. 5d). Ascending motion was present above the sloping frontal surface (Figs. 6a and b). In the next few hours, the frontal zone continued to advance southeastward over the ocean adjacent to northern Taiwan (Figs. 6c and d).

\subsection{Convection over Northern Taiwan and Its Vincinity}

At 20 LST 2 June, the radar reflectivities from the Hualien radar (see Fig. 4 for the location) show north/northeast-south/southwest oriented radar echoes off the northeast of Taiwan (Fig. 7a). From the Kaohsiung radar (see Fig. 4 for the location), it is apparent that these radar echoes moved toward northern Taiwan from the northern Taiwan Strait (Fig. 8a). The Hualien radar did not observe these echoes (Fig. 7a) because of radar beam blockage by the CMR (Fig. 4). Rainfall over the northern Taiwan coast was mainly from the convective systems over the northwestern coast of Taiwan (Fig. 1c) that moved onshore (Fig. 8a). At 23 LST 2 June, the satellite image shows that a northeastsouthwest oriented cloud band stretched from the East China Sea to northern Taiwan (Fig. 9a). Radar echoes over the northeastern Taiwan Strait and the northwestern coast of Taiwan were still evident from the Kaohsiung radar (Fig. $8 b)$. Meanwhile, rainfall continued over the northwestern coast (Fig. 3a). Some of the radar echoes observed over the northeastern Taiwan coast at 20 LST (Fig. 7a) disappeared at this time (Fig. 7b).

At 02 LST 3 June, convective clouds (Fig. 9b) were observed over the northern coast of Taiwan as the surface front approached (Fig. 3b) with radar echoes over the northern coast and adjacent oceans and scattered echoes over the western Taipei Basin (Fig. 7c). Rainfall rates over the northern coast increased (Fig. 3b), consistent with the occurrences of new radar echoes there. The radar echoes over the northeastern Taiwan Strait and northwestern coast of Taiwan observed by the Kaohsiung radar persisted until the early morning of the next day (Fig. 8c).

At $05 \mathrm{LST}$, the northeast/southwest oriented radar echoes moved southeastward and intensified over the northeastern Taiwan coast and the adjacent oceans (Fig. 7d). In the Taipei Basin, the observed radar echoes (Fig. 7d) are consistent with the heavy rainfall recorded there (Fig. 3c). 

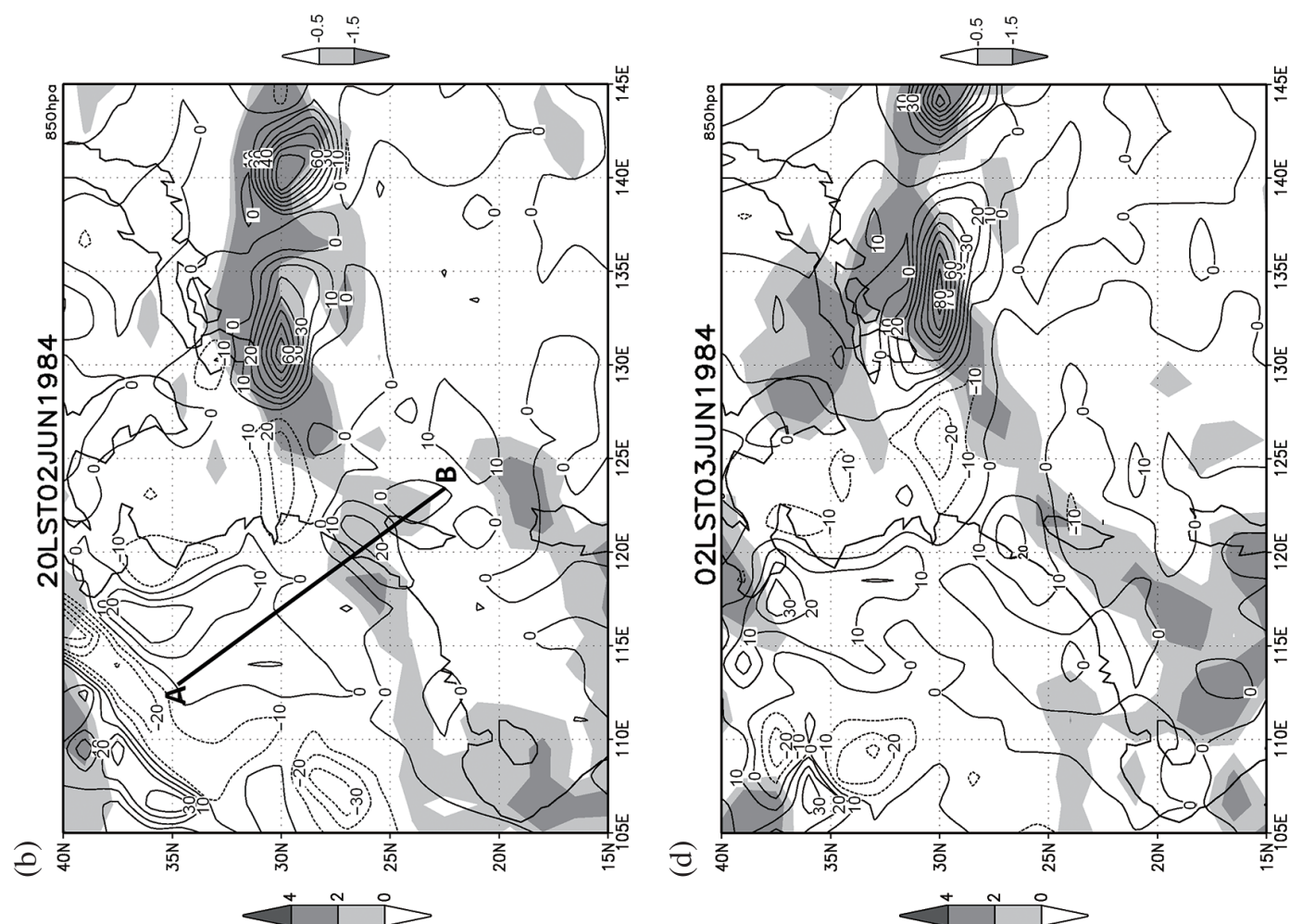

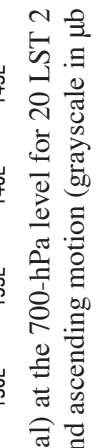
焉㤩 的矛年 응

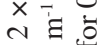
$\Xi \longleftarrow$ 월을 赑 退品告

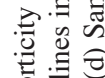
히
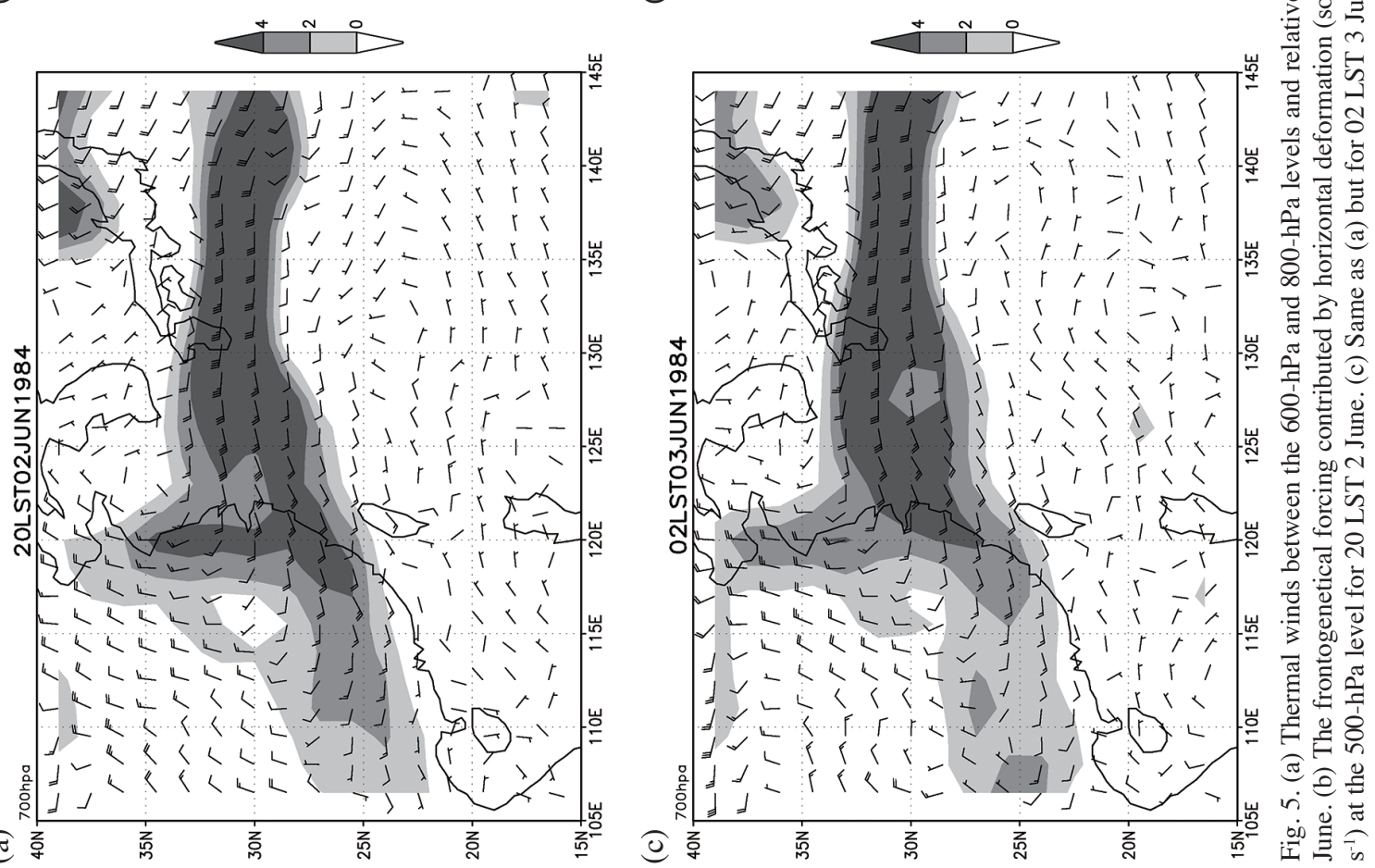
(a)

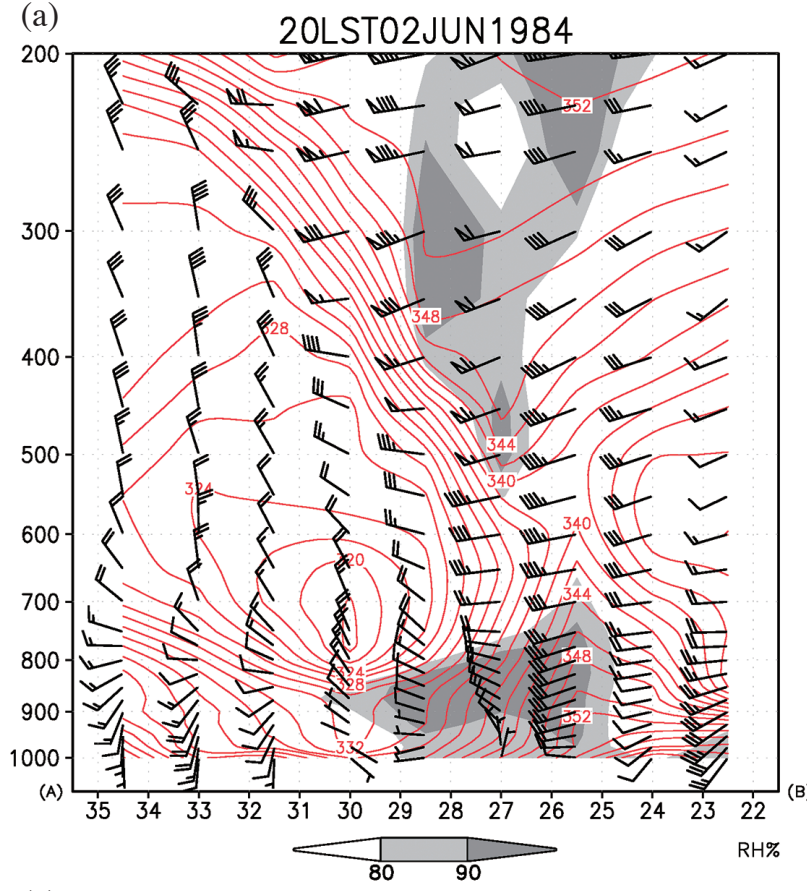

(c)

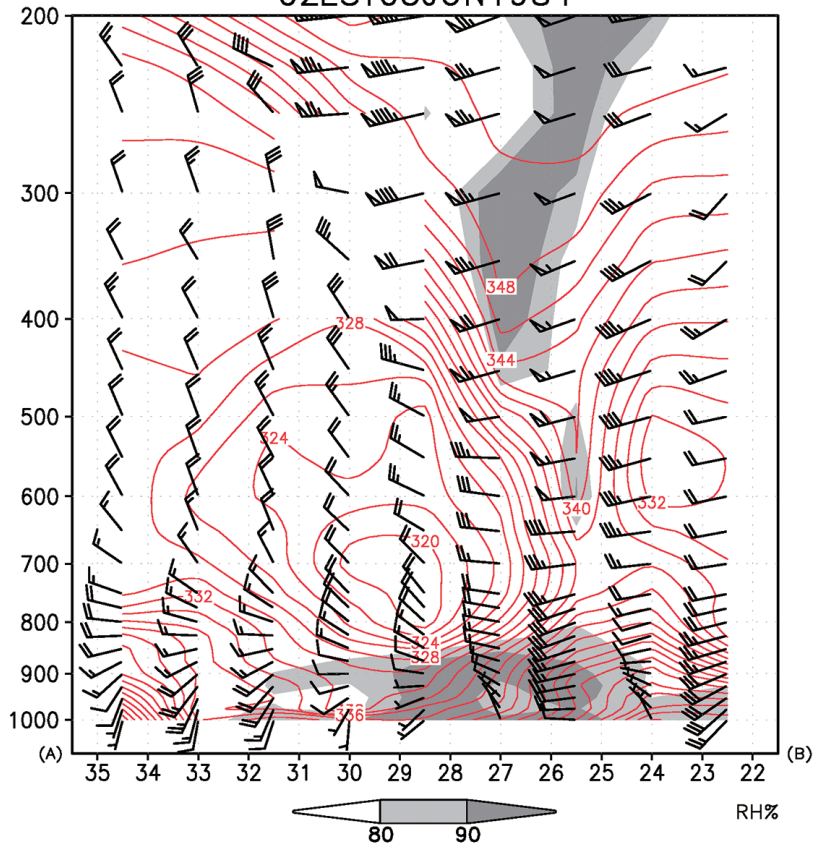

(b) 20LSTO2JUN1984

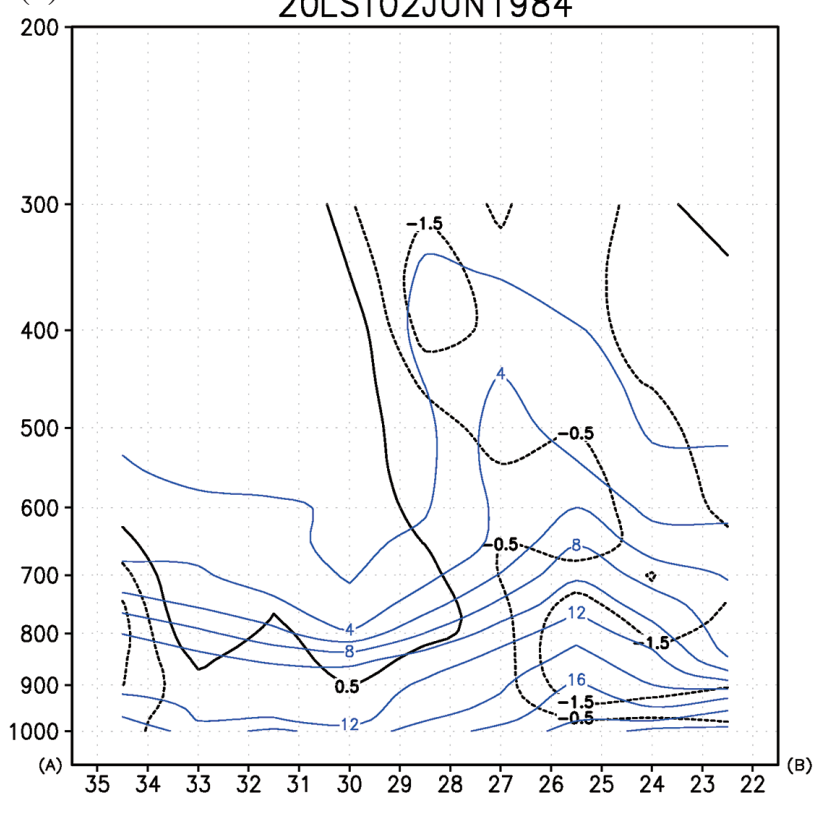

(d)

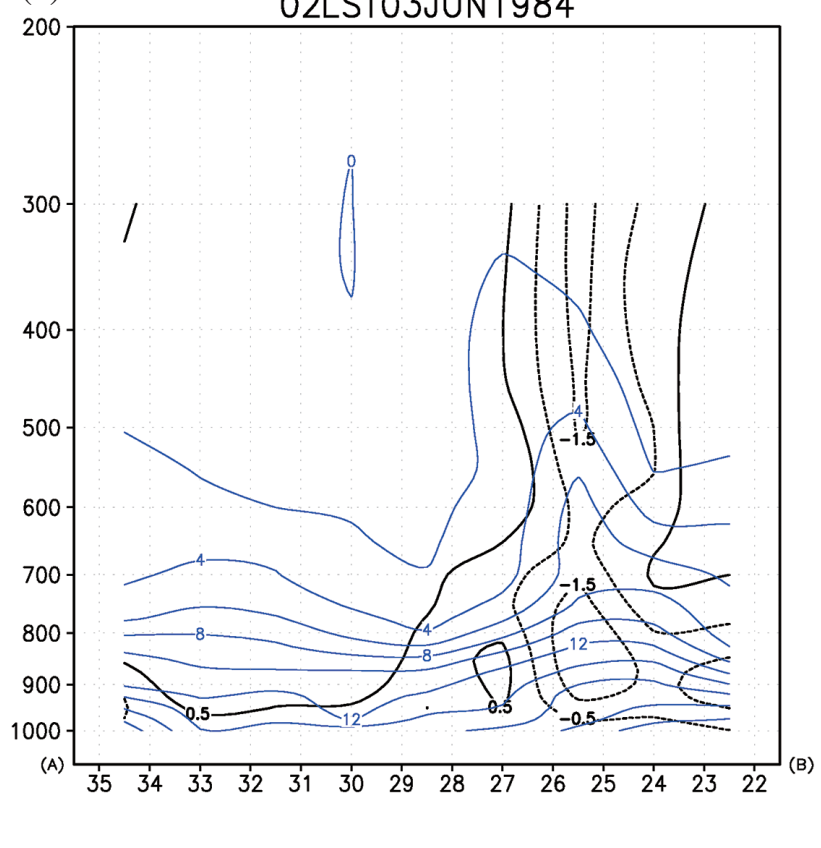

Fig. 6. (a) Equivalent potential temperature (red solid lines every $3 \mathrm{~K}$ ), relative humidity (grayscale in \%), and horizontal winds along line AB in Fig. 5 b for 20 LST 2 June. (b) Water vapor mixing ratio (blue lines every $2 \mathrm{~g} \mathrm{~kg}^{-1}$ ), ascending motion (black dashed lines every $1 \mu \mathrm{b} \mathrm{s}{ }^{-1}$ ) and descending motion (black solid lines every $1 \mu \mathrm{b} \mathrm{s}^{-1}$ ) along line AB in Fig. 5b for 20 LST 2 June. (c) Same as (a) but for 02 LST 3 June. (d) Same as (b) but for 02 LST 3 June. 

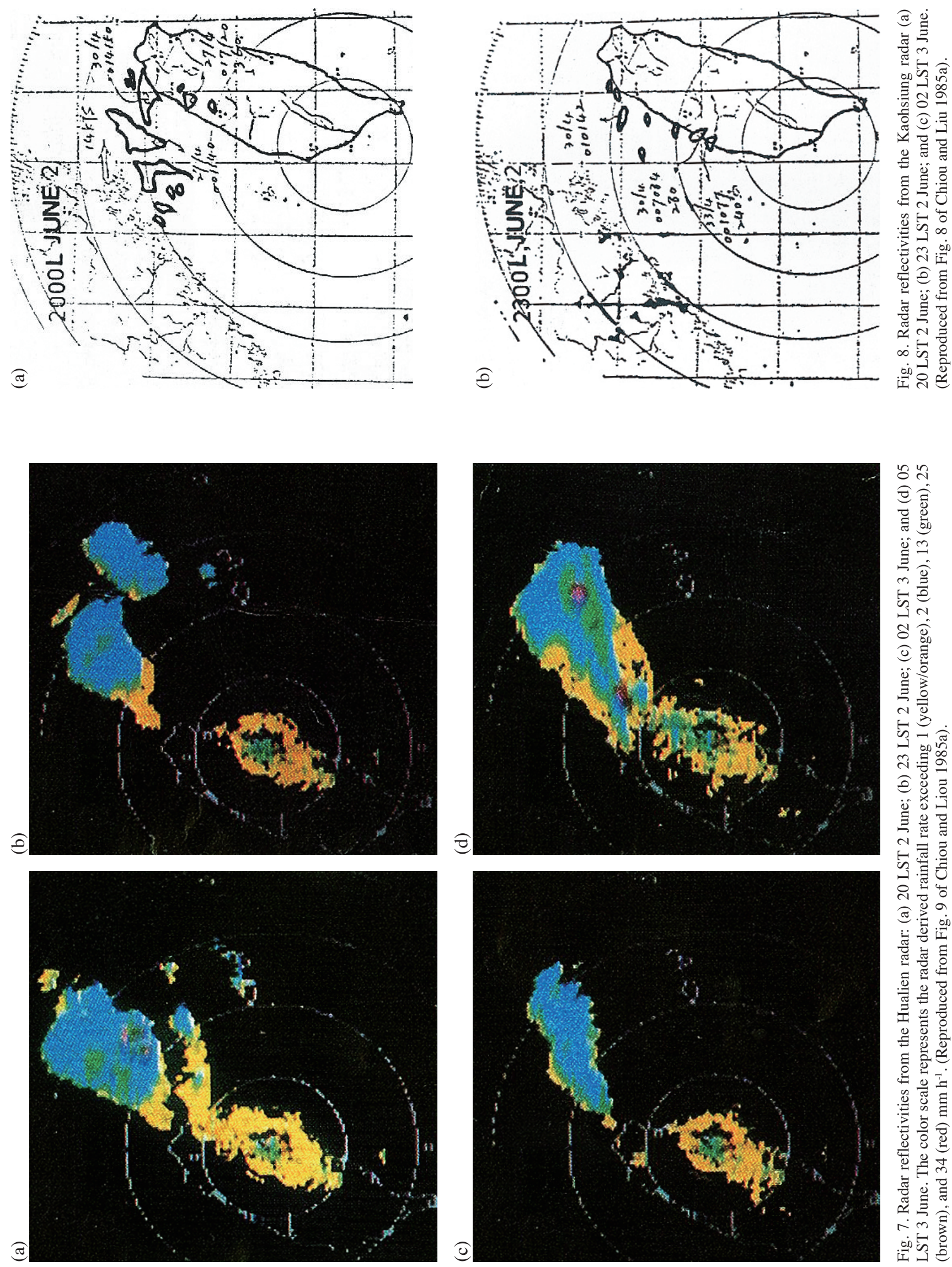

I. 


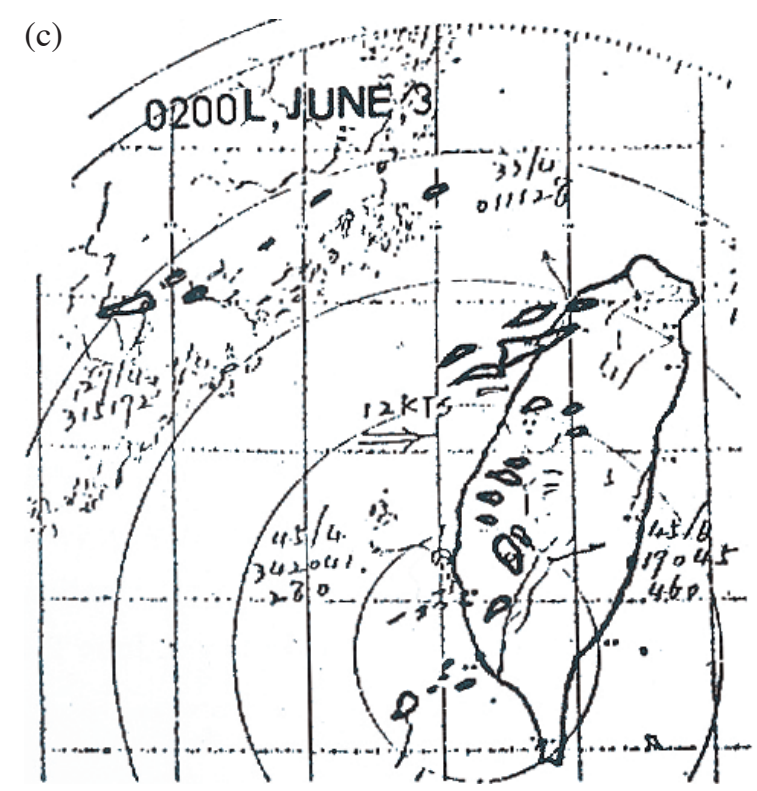

Fig. 8. (Continued)

(a)

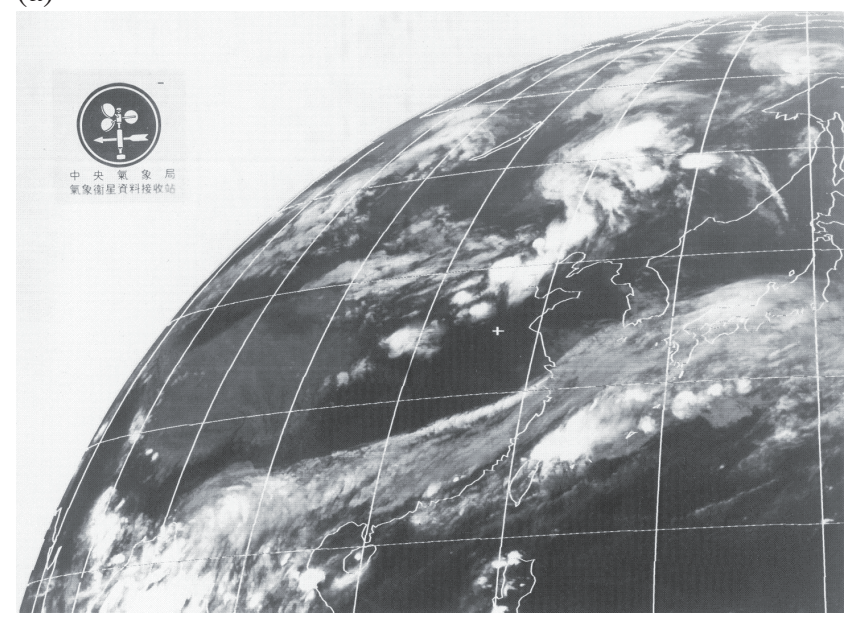

(b)

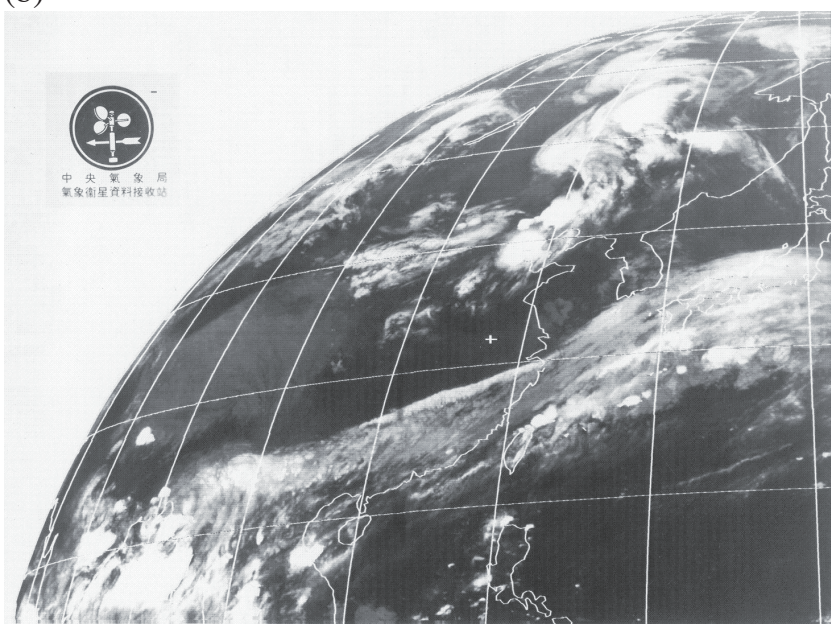

Fig. 9. IR imagery at (a) 23 LST 2 June, and (b) 02 LST 3 June 1984.
Over the northeastern coast of Taiwan at Ilan, rainfall was also recorded (Fig. 3c). At 08 LST 3 June, rainfall intensity decreased in Taipei but rainfall still fell at Suao over northeastern Taiwan (Fig. 3d).

The rainfall over northern Taiwan from the evening of 2 June to the early morning of 3 June before the arrival of a surface front (Fig. 3) is related to the inland drifting of radar echoes over the northwestern coast of Taiwan (Fig. 8). The temporal evolution of rainfall along line AB (Fig. 10c) from the northwestern coast to the Taipei Basin (Fig. 10a) shows that rainfall occurred over the northwestern coast in the evening of 2 June and intensified around 01 LST on 3 June. One to two hours later, heavy rainfall occurred over the western Taipei Basin and the Taipei area.

Within the Taipei Basin, the temporal evolution of rainfall along line CD (Fig. 10c) from Taipei to the slopes south of the Taipei Basin (Fig. 10b) shows that rainfall in the Taipei area started from 03 LST. One to two hours later, rainfall was observed over the slopes south of the Taipei Basin. The southward movement of precipitation is consistent with the southeastward movement of the radar echoes (Fig. 7d). The daily rainfall accumulation exceeds $450 \mathrm{~mm}$ over the northwestern coast of Taiwan and nearly $250 \mathrm{~mm}$ over the Taipei Basin (Fig. 10c).

Over the northern coast of Taiwan, the occurrence of rainfall is related to inland drifting of precipitation from the northern Taiwan Strait before the arrival of the surface front. Within the Taipei Basin, the occurrence of rainfall is related to the approach of precipitation systems from the northeastern Taiwan Strait to the northwestern Taiwan coast as the surface front approached. The mechanisms for the maintenance of the rainfall system and the production of intense localized, heavy precipitation over northwestern Taiwan and the Taipei Basin will be investigated further in section 4 .

\section{EXPERIMENT DESIGN}

The WRF model is employed with nested grids at horizontal grid sizes of $27 \mathrm{~km}$ (domain 1), $9 \mathrm{~km}$ (domain 2), $3 \mathrm{~km}$ (domain 3), and $1 \mathrm{~km}$ (domain 4) (Fig. 11). All grids are comprised of 31 vertical levels ${ }^{1}$ from the surface to the 50-hPa level. In domains 1 and 2, cumulus convection is represented in the model using the subgrid-scale convective parameterization scheme of Kain and Fritsch (1993) and Goddard's grid-resolvable microphysics (Tao et al. 2003). For the $3-\mathrm{km}$ and $1-\mathrm{km}$ grid domains, the convective parameterization scheme is not used. Planetary boundary layer (PBL)

\footnotetext{
${ }^{I}$ The vertical coordinate $\sigma$ is defined as $\left(p-p_{t}\right) /\left(p_{s}-p_{t}\right)$, where $p$ is pressure, $p_{s}$ is surface pressure, and $p_{t}$ is a constant pressure $(50 \mathrm{hPa})$ at the top of the model. The 31 sigma levels are 1.0, 0.993, 0.98, 0.966, 0.95, 0.933, $0.913,0.892,0.869,0.844,0.816,0.786,0.753,0.718,0.680,0.639,0.596$, $0.550,0.501,0.451,0.4398,0.345,0.29,0.236,0.188,0.145,0.108,0.075$, $0.046,0.021$, and 0.0 .
} 
(a)

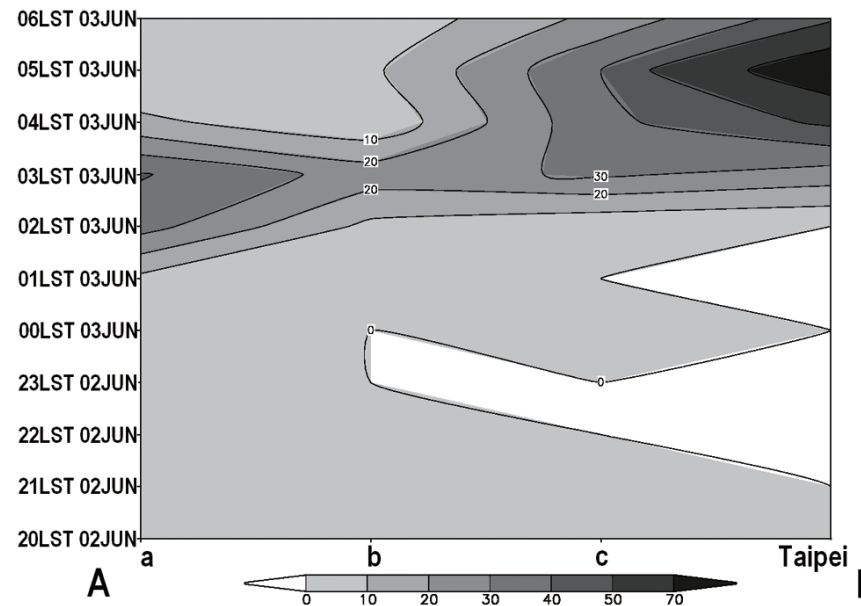

(c)

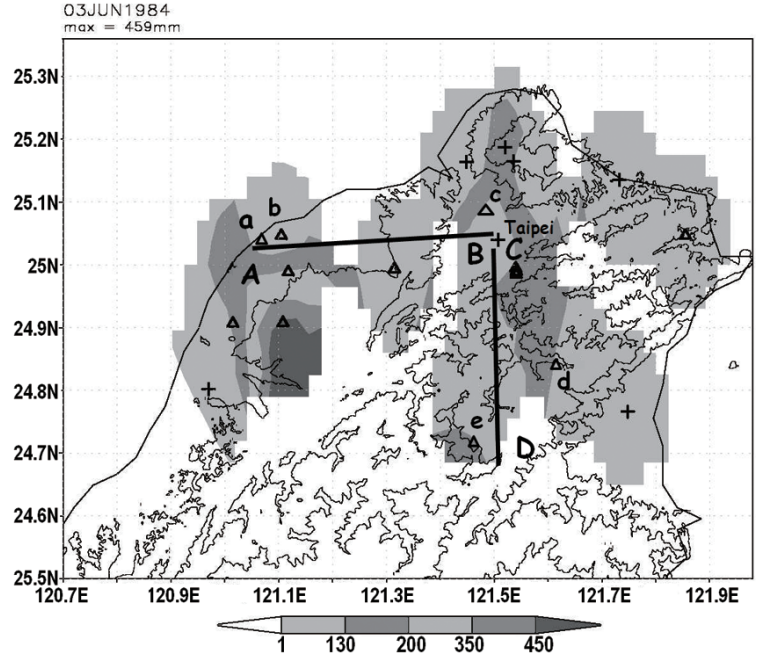

(b)

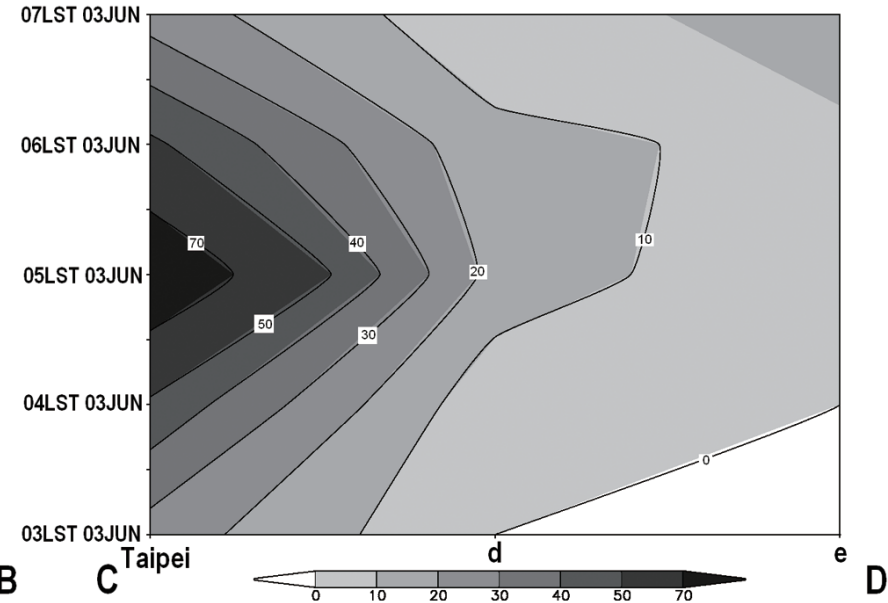

Fig. 10. (a) Temporal evolution of rainfall along line AB in Fig. 10c. The locations of stations a, b, and c are shown in Fig. 10c. Hourly rainfall rate $\left(\mathrm{mm} \mathrm{h}^{-1}\right)$ is shown by the grayscale. (b) Same as (a) but for Line CD in Fig. 10c. The locations of Station d and e are shown in Fig. 10c. (c) Daily rainfall accumulation (mm) on 3 June 1984 shown by the grayscale. The conventional stations are denoted by crosses. Rainfall stations from the Civil Aeronautics Administration and the Water Resources Agency are represented by triangles. Line AB and Stations a, b, c and Taipei are used in Fig. 10a. Line CD and Station Taipei, d, and e are used in Fig. 10b. Terrain contours (dotted lines) are 200, 500, and $1500 \mathrm{~m}$, respectively.

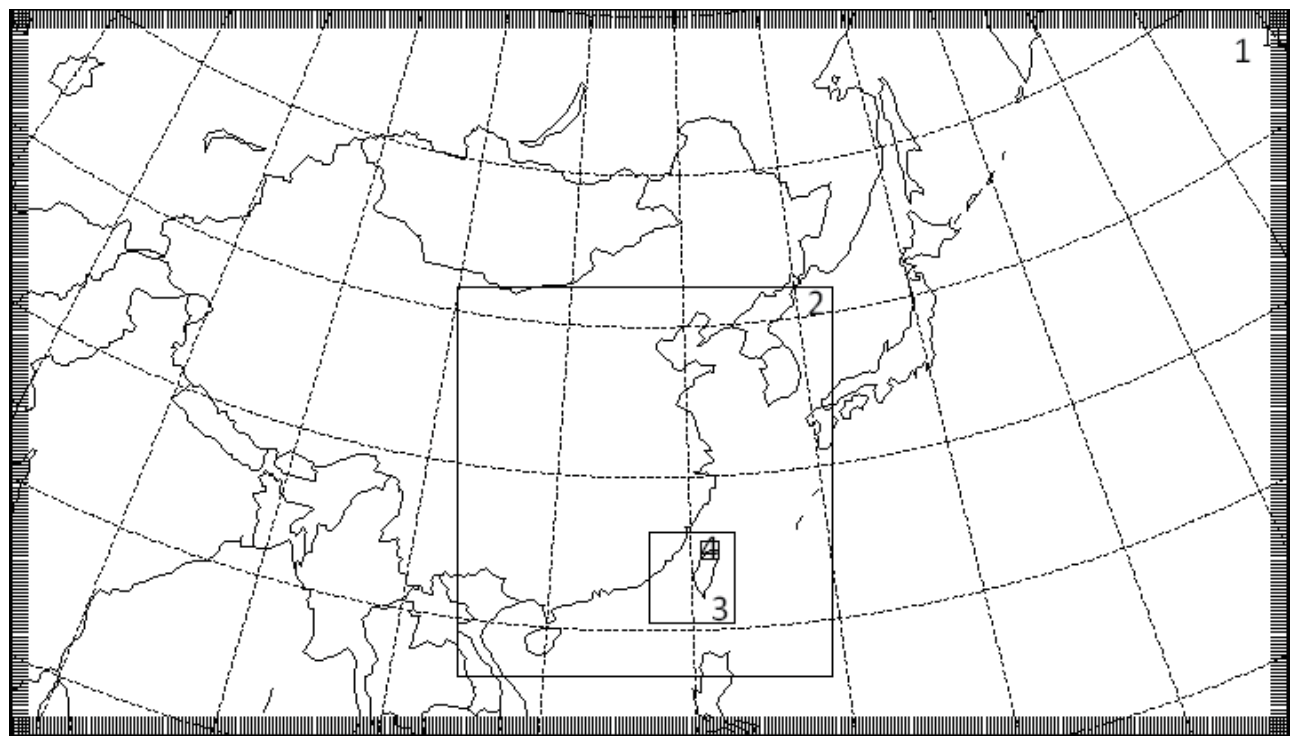

Fig. 11. The model configuration. The horizontal grid sizes for domains 1 - 4 are 27, 9, 3, and $1 \mathrm{~km}$, respectively. 
processes are represented by the Mellor-Yamada-Janjic TKE scheme (Janjić 1996, 2002). The land surface model is the 5-layer thermal diffusion model (Dudhia 1996). The model is initialized from the ECMWF analysis at 0800 LST (0000 UTC) 2 June 1984 and integrated for 48 hours.

Model results from the 9-km grid domain are used to validate the simulated subsynoptic weather patterns in comparison with the ECMWF analysis. The 9-km grid domain is also used to describe the propagation of the surface frontal system and associated rainfall distribution over the southeastern China coast and the Taiwan area in comparison with the surface, satellite, and radar data. Convectionsallowing models ( 3 and $1 \mathrm{~km}$ ) produce useful insights on the orographic effects on the intensification of convective systems as they move toward the northern Taiwan coast and the impact of terrain on orographic precipitation over the Taipei Basin. In order to assess the impact of Taiwan's topography on the horizontal distribution of heavy rainfall patterns, a sensitivity test without the topography of Taiwan is performed (NT run) to compare with the results from the run including the topography of Taiwan (CR run).

The possible enhancement of rainfall caused by the interaction between the outflow boundary and the environmental flow will be investigated from the simulated surface temperature and winds in the convective areas. The simulated evolution and horizontal distributions of rainfall patterns from convections-allowing models are verified against surface rainfall data.

\section{RESULTS OF SIMULATIONS}

\subsection{Evolution of Simulated Weather Patterns for the 9-km Regional Grid Domain}

At 20 LST 2 June, the upper-level divergence over the southeastern coast of China and the Taiwan Strait is simulated (Fig. 12a), in agreement with observations (Fig. 1a).
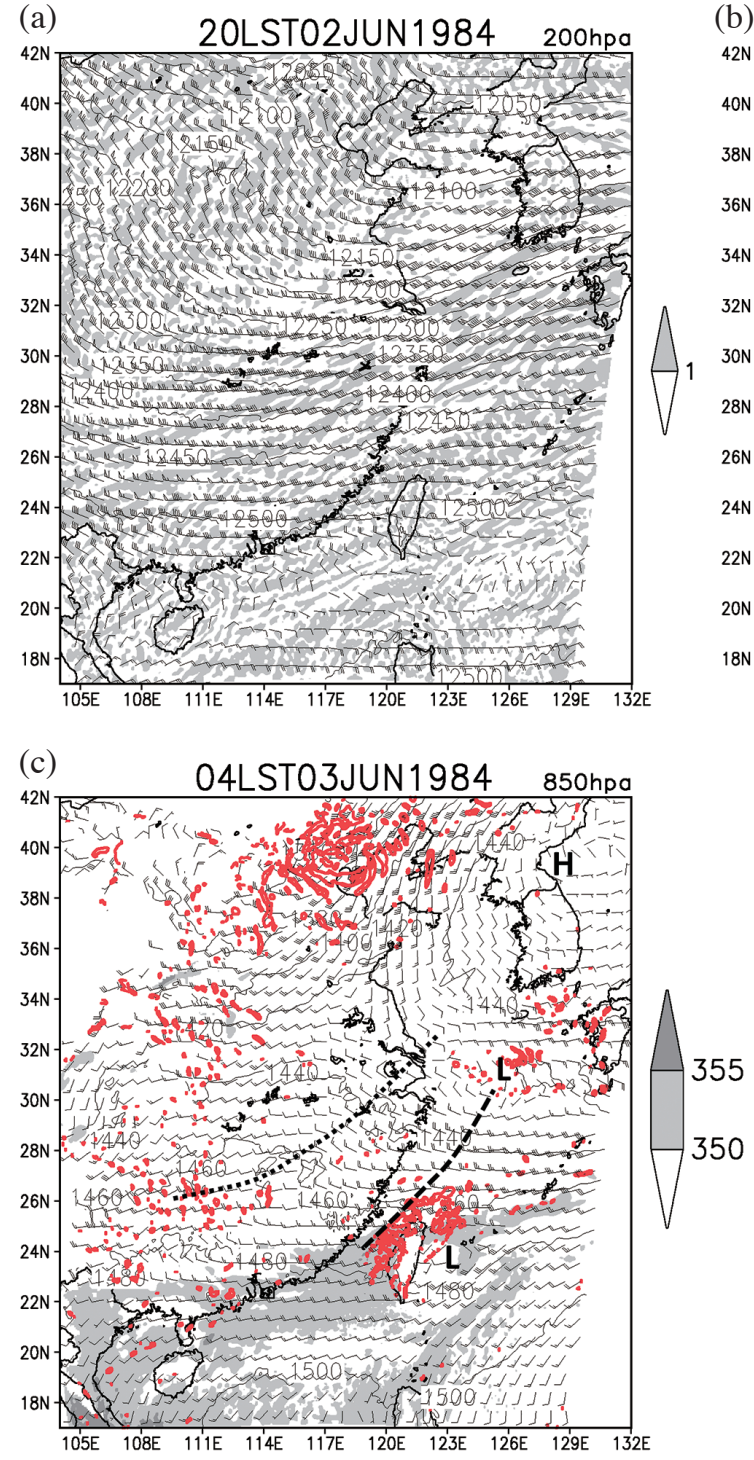

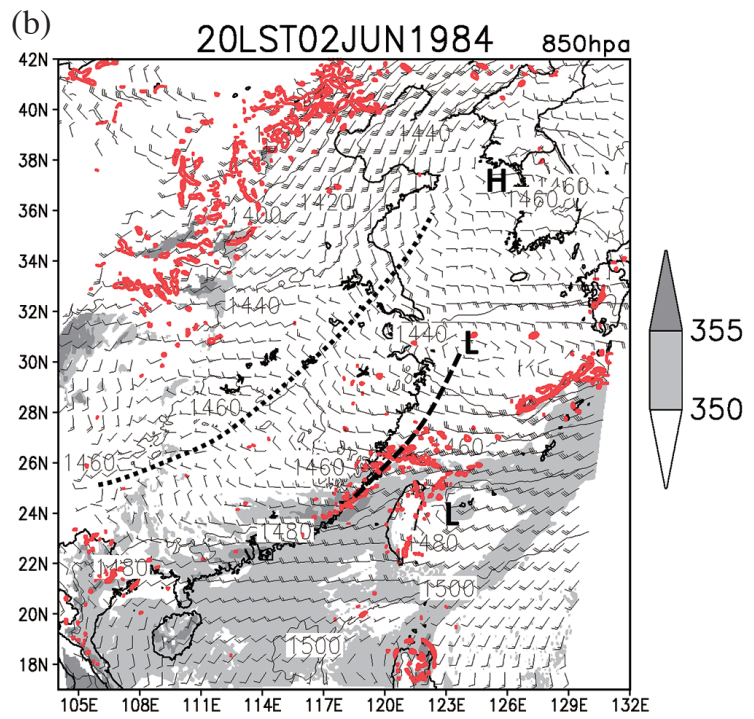

Fig. 12. (a) Simulated 200-hPa geopotential heights (solid lines, every $50 \mathrm{gpm}$ ) and winds at 20 LST 2 June for the 9-km grid domain simulation. The shaded areas represent divergence greater than $1 \times 10^{-5} \mathrm{~s}^{-1}$. (b) Simulated 850-hPa geopotential heights (solid lines, every $20 \mathrm{gpm}$ ), and winds at 20 LST 2 June for the $9-\mathrm{km}$ grid domain simulation. The dotted (dashed) line denotes the approximate position of the trough (windshift line) at the $500-\mathrm{hPa}$ (850-hPa) level. The areas with ascending motion greater than $0.1 \mathrm{~m} \mathrm{~s}^{-1}$ are shaded in red. The selected equivalent potential temperature is denoted by shaded areas. $\mathrm{H}$ denotes a high pressure center. L denotes the synoptic low pressure center over the East China Sea and a mesolow to the east of Taiwan. (c) Same as (b) but for 04 LST 3 June. 
At the 500-hPa level, the observed trough, which stretches from the East China Sea to southern China (Fig. 1b), is also reproduced (Fig. 12b). At the 850-hPa level, the observed patterns (Fig. 1b), including the windshift line along the trough axis over the southeastern China coast, westerly flow over the southern Taiwan Strait, and west-southwesterly flow over the Taiwan Strait with increasing strength over the northwestern coast are also simulated (Fig. 12b). Subsynoptic-scale ascending motion is simulated over the southeast China coast associated with the $850-\mathrm{hPa}$ trough, as well as north of Taiwan (Fig. 12b) associated with the surface front (Fig. 13a). High $\theta_{\mathrm{e}}$ air is simulated in the prefrontal southwesterly monsoon flow ahead of the $850-\mathrm{hPa}$ trough and over the Taiwan Strait (Fig. 12b) in agreement with observations (Figs. 1b and 6a).

From 20 LST 2 June to 12 LST 3 June, we simulated the surface front and vertically integrated grid-scale rainwater from the southeastern China coast to northern Taiwan (Fig. 13). At 20 LST 2 June, the simulated surface front, represented by changes in surface wind direction and temperature, extends from the East China Sea to the ocean east of northeastern Taiwan, and then westward to the southeastern China coast (Fig. 13a), consistent with observations (Fig. 1c). The simulated vertically integrated rainwater associated with the low-level trough (Fig. 12b) over the southeastern China coast is consistent with satellite images (Chiou and Liu 1985a). The vertically integrated rainwater is also simulated in the frontal zone north of Taiwan, corresponding to the observed radar echoes in these areas (Fig. 7a). However, over the northeastern Taiwan coast, the observed radar echoes (Fig. 7a) are not simulated (Fig. 13a). Over the ocean east of Taiwan, a mesolow resulting from an adiabatic decent in the lee (Sun et al. 1991) is simulated.

At 23 LST 2 June, the western part of the simulated surface front remains over the southeastern China coast whereas the eastern part of the surface front is located north of the Taiwan Strait and northern Taiwan (Fig. 13b), in agreement with observations (Fig. 3a). Vertically integrated rainwater is simulated over the northern Taiwan Strait and to the north of Taiwan, corresponding to the observed radar echoes in these areas (Figs. $7 \mathrm{~b}$ and $8 \mathrm{~b}$ ).

At 02 LST 3 June 1984, the western part of the simulated surface front moves off the southeastern coast of China to the northwestern Taiwan Strait (Fig. 13c). The eastern part of the surface front moves southward to the ocean adjacent to northeastern Taiwan (Fig. 13c), in agreement with the analysis (Fig. 3b). The rainfall systems simulated earlier over the northern/central Taiwan Strait (Fig. 13b) reach the northwestern Taiwan coast ahead of the simulated surface front (Fig. 13c). The evolution of simulated rainwater over the northeastern Taiwan Strait and the northwestern Taiwan coast is consistent with the radar echoes from the Kaohsiung radar (Fig. 8) and satellite data (Fig. 9b).

At 04 LST, the simulated 500-hPa trough moves to the eastern China coast whereas the simulated $850-\mathrm{hPa}$ trough axis is over the northern Taiwan Strait (Fig. 12c). The simulated surface front is over northern Taiwan (Fig. 13d) in agreement with observations (Fig. 3c). Rising motion is simulated ahead of the NNE-SSW oriented trough axis and in the frontal zone (Fig. 12c). From 20 LST 2 June to 04 LST 3 June, the simulated vertically integrated rainwater increases as it moves southeastward and reaches northern Taiwan. The enhancement of the simulated rainwater over northern Taiwan in the early morning of 3 June is consistent with rainfall observations (Fig. 10). In addition to subsynoptic weather patterns, the airflow and precipitation are also affected by orographic effects as the low-level trough and the surface front move toward the Taiwan area. Note that with the strengthening of the prefrontal southwesterly monsoon flow as the surface front approaches, scattered heavy convective cells are simulated off the western coast of Taiwan where the orographically deflected flow along the coast merges with the prevailing southwesterly flow over the Taiwan Strait (Fig. 13d). More discussion of orographic enhancement of precipitation will be presented in section 4.2.

At 06 LST, the simulated surface front over northern Taiwan (Fig. 13e) is consistent with observations (Fig. 3). The horizontal distribution of simulated vertically integrated rainwater (Fig. 13e), which is located in the warm sector of the surface front and oriented in a northeast-southwest direction over the northern and northeastern part of Taiwan and the adjacent ocean, is in agreement with the radar echoes (Fig. 7d).

From 09 to 12 LST, the simulated surface front continues to move southeastward (Figs. 13f and g) consistent with observations (Fig. 3d). The maximum axis of the simulated northeast-southwest oriented vertically integrated rainwater over the Taipei Basin decreases (Fig. 13g), in agreement with the decrease of observed rainfall in the Taipei Basin (Fig. 10b).

\subsection{The Mechanisms for the Development and Mainte- nance of Heavy Rainfall over the Northwest Coast and the Taipei Basin}

\subsubsection{Orographic Effects as the Low-Level Trough Ap- proaches Taiwan}

Previous studies (Li et al. 1997; Yeh and Chen 2002, 2003) showed that under favorable large-scale conditions, the localized offshore convergence due to the interaction between the barrier jet and the prevailing winds plays an important role in the commencement/occurrence of localized heavy rainfall over the northwestern coast of Taiwan. The mechanism for the development of strong low-level south-westerly flow over the northwestern coast of Taiwan (or barrier jet) was first studied by Li and Chen (1998). For our case, as shown in section 4.1, at 23 LST 2 June, the preexisting precipitation systems are simulated associated with 
the NNE-SSW oriented trough over the southeastern China coast and in the frontal zone north of Taiwan (Fig. 13b). Those precipitation areas advance southeastward and reach northwestern and northern Taiwan during the early morning of 3 June and are related to the evolution of the $850-\mathrm{hPa}$ trough (Fig. 12) and the surface front (Fig. 13). During 02 - 12 LST 3 June, the southwestern portion of the simulated NESW oriented vertically integrated rainwater off the northwestern Taiwan coast is considerably greater than its northeastern counterpart, which is on the lee-side of the prevailing southwesterly monsoon flow. In this section, the possible orographic enhancement of precipitation over the northwestern coastal area and the Taipei Basin will be investigated from the results of our convection-allowing models with a $3-\mathrm{km}$ resolution.

At 20 LST 2 June, high maximum radar reflectivities are simulated over the southeastern China coast (Fig. 14a), under favorable large-scale settings (Figs. 12a and b). Over the southwestern Taiwan coast, the in-coming southwesterlies decelerate with flow splitting offshore as a result of orographic blocking (Fig. 14a), similar to the TAMEX IOP 13 case ( $\mathrm{Li}$ et al. 1997). The low-level convergence associated with orographic blocking is evident over the southwestern coast of Taiwan and the adjacent ocean (Fig. 15a).

At 23 LST 2 June, the simulated low-level windshift line associated with the trough axis moves to the northern Taiwan Strait with strengthening of the pre-frontal southwesterly flow (Fig. 14b). The deflected southerly flow along the west coast accelerates downstream (Fig. 16a) toward lower pressure over the northwestern coast to become a barrier jet as found by Li and Chen (1998). The simulated convective area associated with the $850-\mathrm{hPa}$ trough is enhanced as it moves to the northern Taiwan Strait where the orographically deflected flow with a large southerly wind component converges with the prevailing flow (Fig. 13b).

During 23 LST 2 June - 02 LST 3 June, low-level convergence is simulated off the northwestern and western coasts where the prevailing southwesterly flow within the Taiwan Strait converges with the orographically deflected flow with a southerly wind component off the western/northwestern Taiwan coast (Figs. 15b and c), similar to the TAMEX \# IOP 3 case reported by Yeh and Chen (2002). The simulated high reflectivity areas migrate from southeastern China coast and north of Taiwan (Fig. 14a) to the northern/central Taiwan Strait (Figs. 14b and c). The simulated convective rainfall areas are enhanced in the northern/central Taiwan Strait (Figs. 14b and c) as they move over the low-level convergence zone as a result of orographic blocking.

As will be shown in section 4.2.2, at 02 LST 3 June, the low-level convergence near $25^{\circ} \mathrm{N}$ is further enhanced by convergence along the outflow boundary due to rain evaporative cooling. To the south of $25^{\circ} \mathrm{N}$, the low-level convergence mainly occurs between the barrier jet and the southwesterly flow (Fig. 15c) along the northwestern coast of Taiwan as the windshift line associated with the trough axis approaches.

At 04 LST 3 June, as the $850-\mathrm{hPa}$ trough migrates eastward (Fig. 12c), the low-level northwesterly/westerly flow behind the windshift line associated with the trough axis, converge with the barrier jet off the northwestern coast of Taiwan (Fig. 15d) as found by Li et al. (1997) for the TAMEX IOP \# 13 case. A high reflectivity area (Fig. 14d) with maximum vertically integrated rainwater (Fig. 13d) occurs off the northwestern coast of Taiwan. During $02-06$ LST, scattered showers are simulated off the western coast where the prevailing south/southwesterly flow from the Taiwan Strait encounters an orographically deflected flow along the coast with a large southerly wind component (Figs. 14c, d, and e).

During 04 - 06 LST 3 June, the high reflectivity area over the northwestern/northern coast of Taiwan (Figs. 14d and e) moves to the Taipei Basin as the surface front arrives (Figs. 3c, 13d, and e). Concurrently, the windshift line associated with the trough axis arrives off the northwestern coast of Taiwan (Fig. 14e). The inland-movement reflectivity area is enhanced by the strong low-level convergence (Figs. 15d and e) over northern Taiwan and the northwestern coast of Taiwan. Furthermore, the orographic lifting of the southwesterly flow over the slopes south of the Taipei Basin (south of $24.8^{\circ} \mathrm{N}$ in Fig. 17) is also important for the occurrence of localized heavy rainfall there. At 09 LST, as the windshift line associated with the trough axis arrives at northern Taiwan, the low-level convergence over northern Taiwan across the windshift line associated with the trough axis is evident (Fig. 15f). The simulated radar reflectivities over northern Taiwan (Fig. 14f) are strengthened by the low-level convergence (Fig. 15f). During 09 - 12 LST, the windshift line associated with the trough axis continues to move southeastward (Fig. 14g). Currently, the low-level convergence over northern Taiwan decreases (Fig. 15g), the high reflectivity area moves southward away from the Taipei Basin, and precipitation decreases in the Taipei Basin.

Unlike findings from previous studies (Li et al. 1997; Yeh and Chen 2002), the drifting of pre-existing convection inland is the precursor for the occurrence of localized heavy rainfall in the northwestern Taiwan coast and the Taipei Basin. As the pre-existing convective areas move toward the northwestern coast and northern Taiwan, they are enhanced by orographic effects as a result of orographic blocking. The localized low-level convergencealong the low-level windshift line occur over the northeastern Taiwan Strait and the northwestern coast approximately to the west of the Taipei Basin when the inland-drifting convective areas arrive (Fig. 14). Furthermore, in the current study, only the southwestern end of the windshift line associated with the trough axis at the 850 -hPa level propagates across the northwestern Taiwan Strait (Figs. 1b and 14) and moves eastward, bringing in localized heavy rainfall over northwestern coast and 


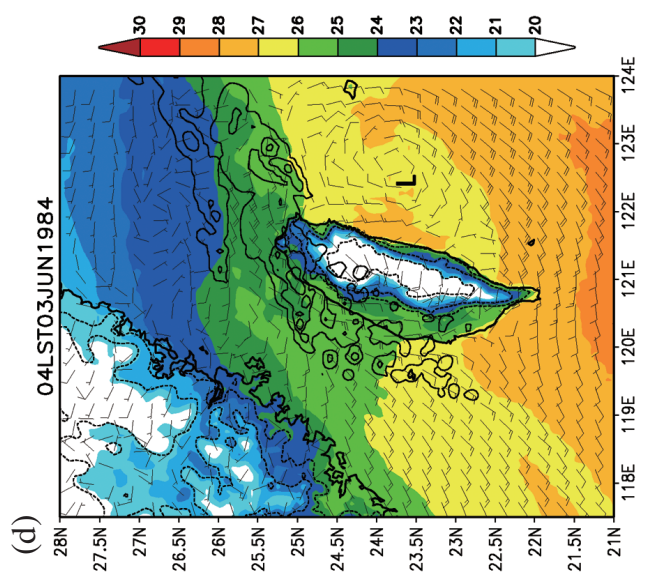

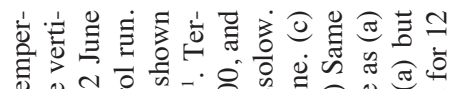

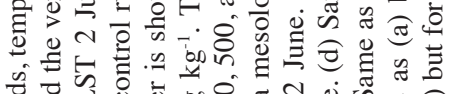

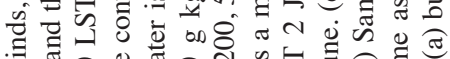

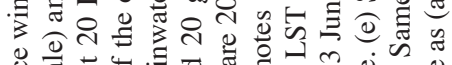

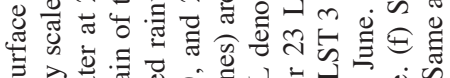

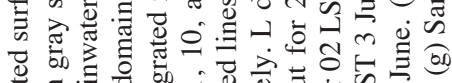

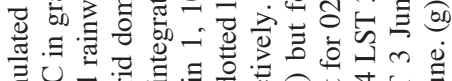

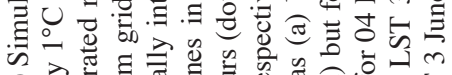

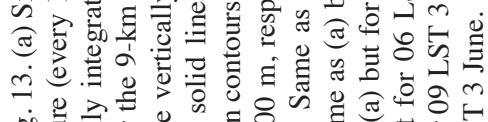

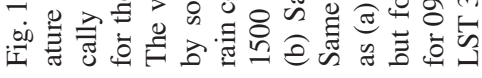
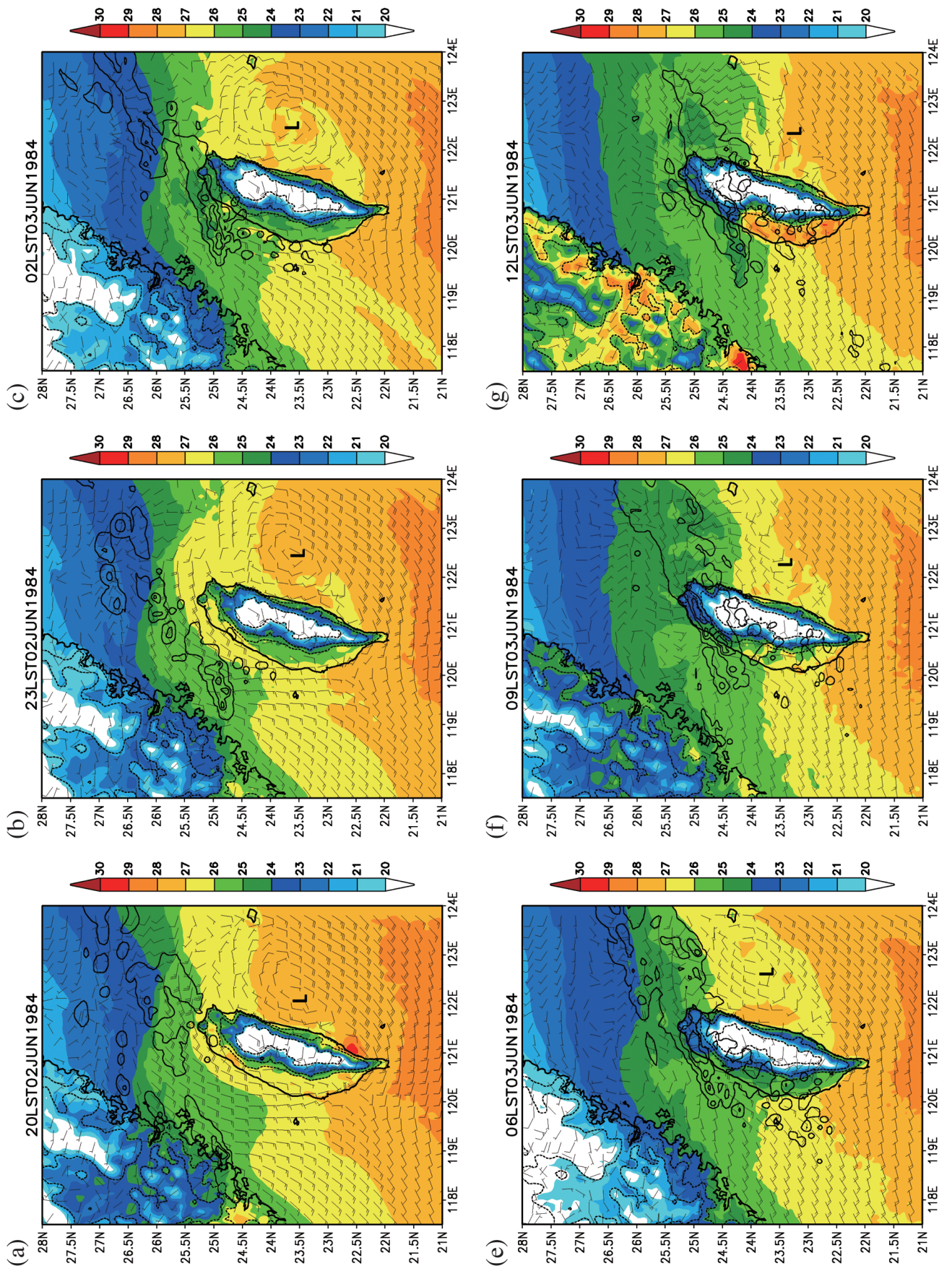


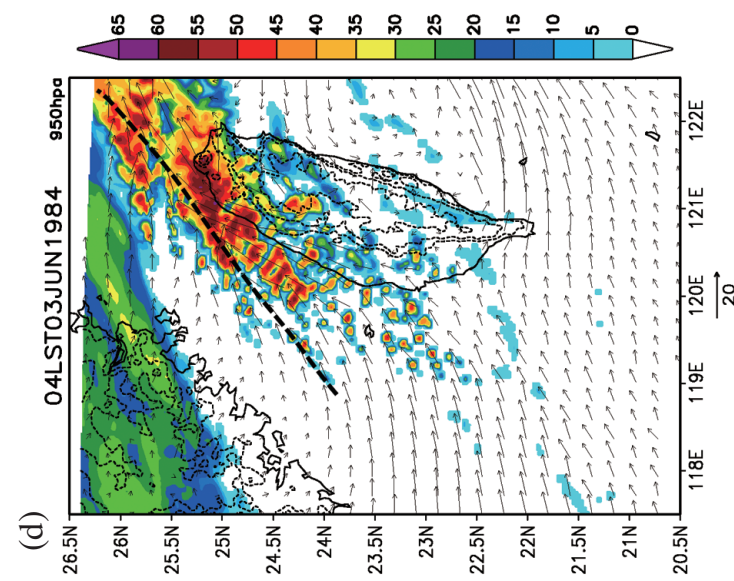

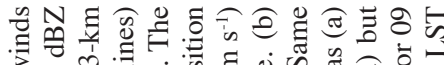

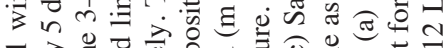

$\vec{D}$

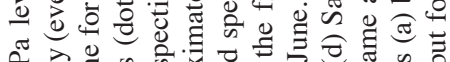

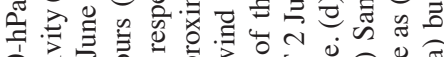

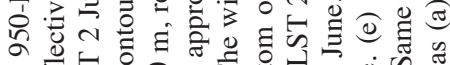

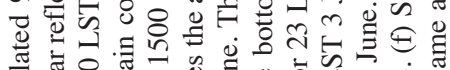

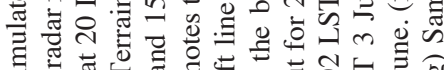

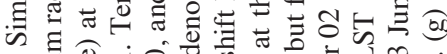

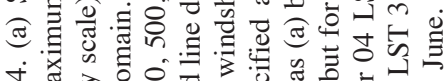

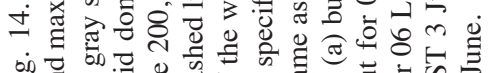

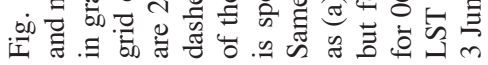
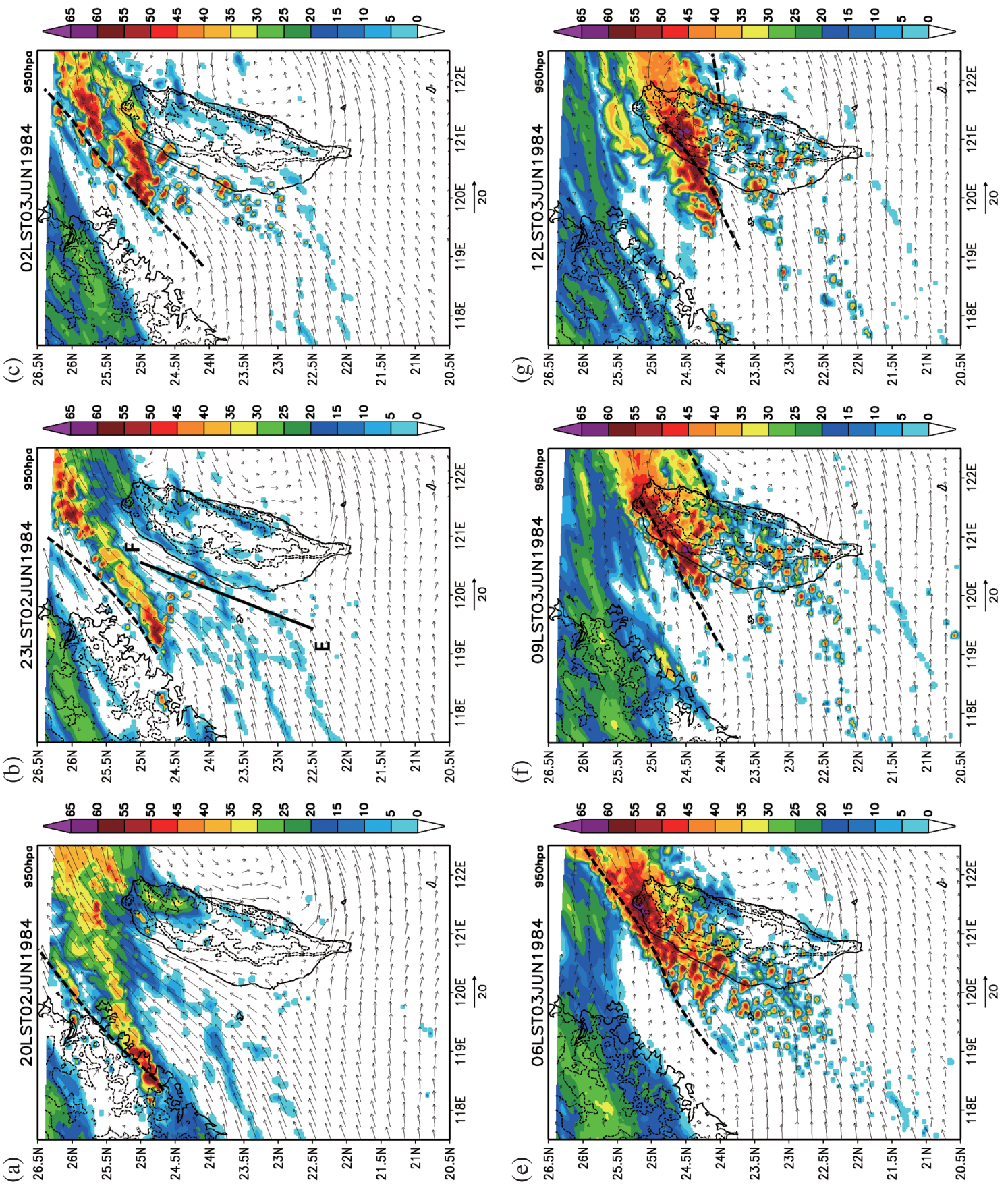

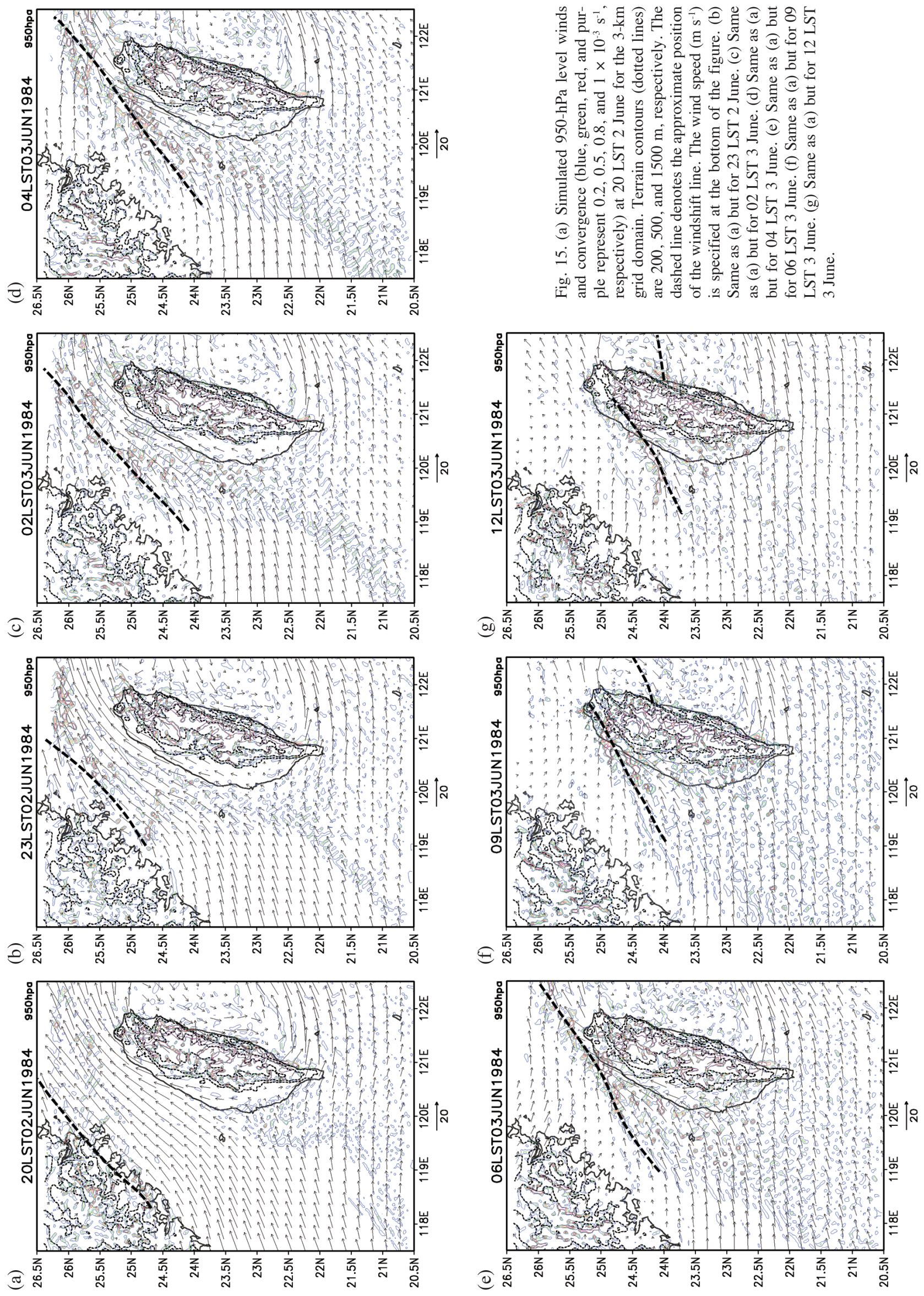

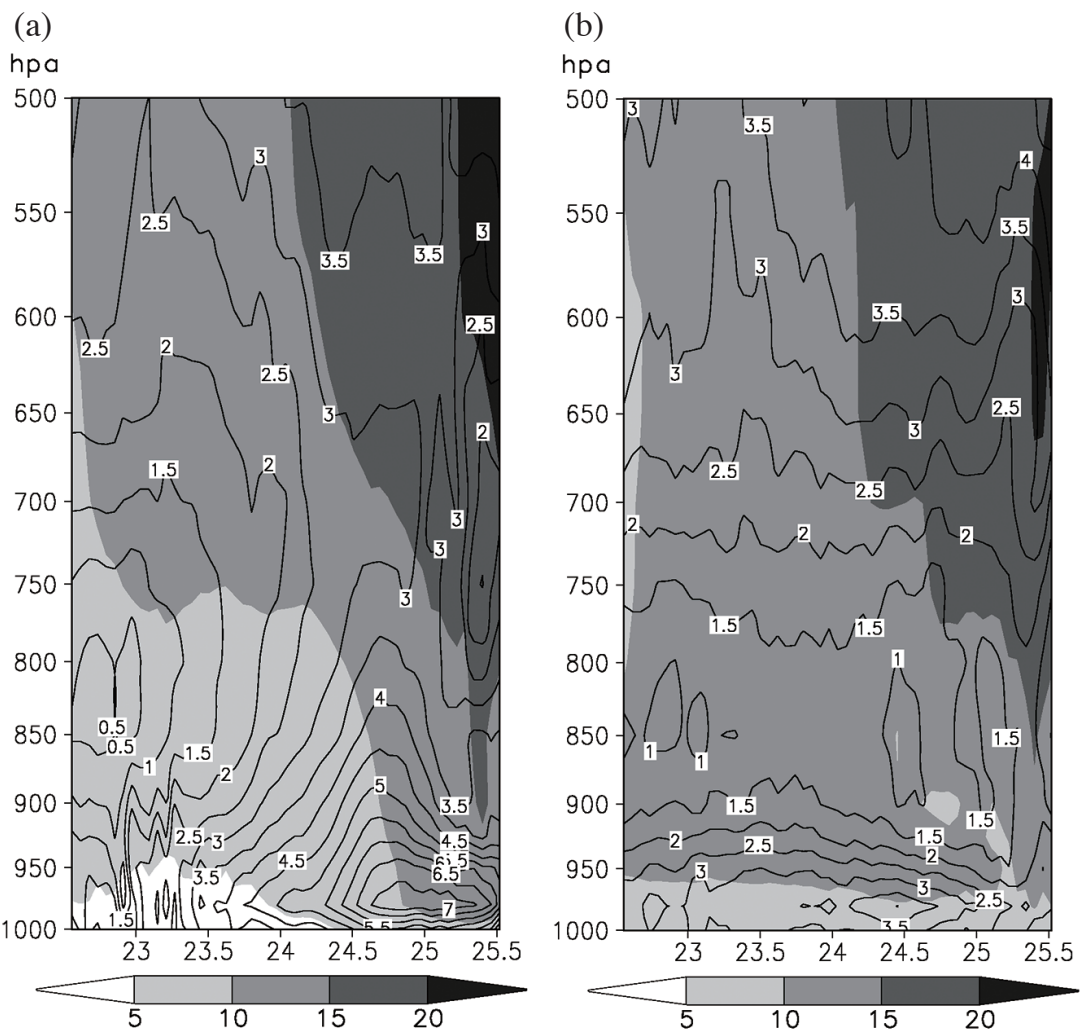

Fig. 16. (a) Simulated meridional winds (solid lines) for the vertical cross section along Line EF (Fig. 14b) at 23 LST 2 June. Contour interval is $0.5 \mathrm{~m} \mathrm{~s}^{-1}$. The simulated u-component wind along Line EF $\left(\mathrm{m} \mathrm{s}^{-1}\right)$ in Fig. 14b is shown by the grayscale. (b) Same as (a) but for the NT run.

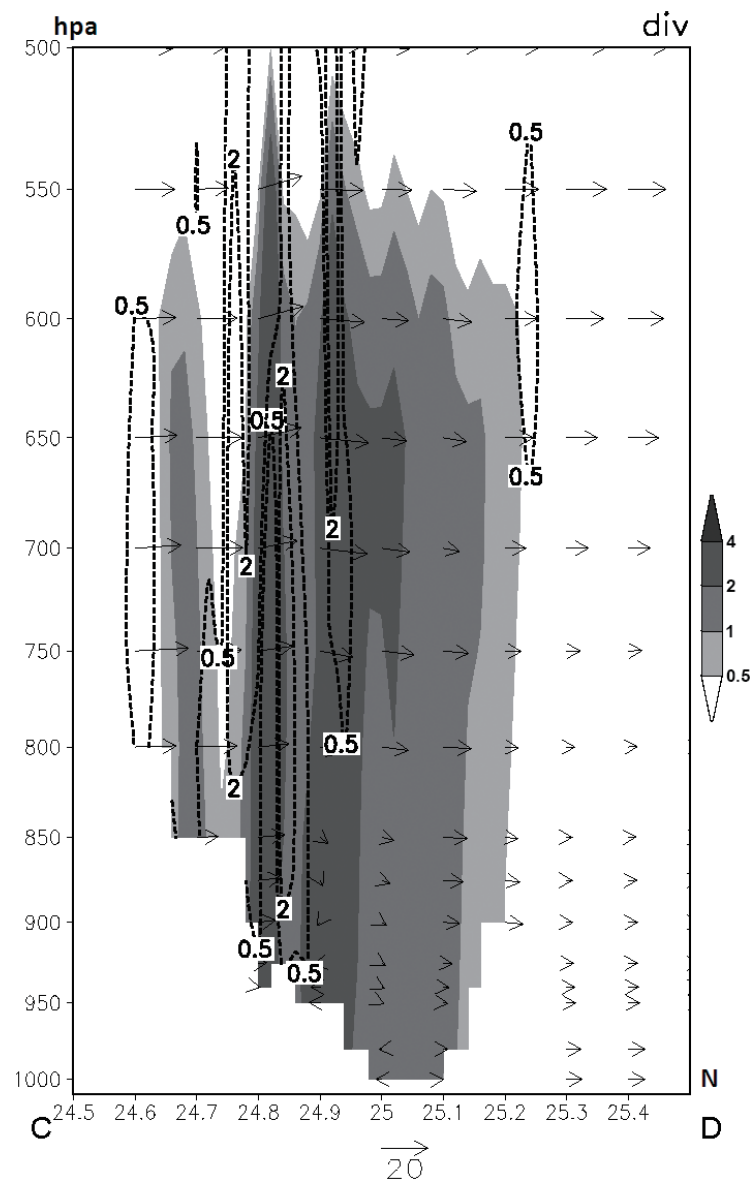

Fig. 17. Vertical cross section along Line CD (Fig. 20a) at 07 LST 3 June for simulated rainwater (in grayscale in $\left.\mathrm{g} \mathrm{kg}^{-1}\right)$, the wind component along the cross section $\left(\mathrm{m} \mathrm{s}^{-1}\right)$ and ascending motion in 0.5 and $2 \mathrm{~m} \mathrm{~s}^{-1}$ (dashed lines). The wind speed $\left(\mathrm{m} \mathrm{s}^{-1}\right)$ is specified at the bottom of the figure. 
northern Taiwan. The location of the localized low-level convergence in previous case studies ( $\mathrm{Li}$ et al. 1997; Yeh and Chen 2002) during the initiation of convective systems is southwest of the Taipei Basin, which resulted in heavy rainfall further to the south after these convective systems move onshore. Nevertheless, for all three cases studied, localized heavy rainfall occurs at night as the surface front approaches with increasing strength of the pre-frontal southwesterly monsoon flow. Previous studies have shown that orographic blocking is most pronounced at night and in the early morning when the land surface is coldest (Chen and $\mathrm{Li}$ 1995b; Kerns et al. 2010; Lin et al. 2011).

In the NT simulation with a $9-\mathrm{km}$ grid domain, at 20
LST 2 June, the simulated surface front and associated gridscale vertically integrated rainwater over the East China Sea and southeastern China (Fig. 18a) is similar to that in the control run (CR) (Fig. 13a). At 02 LST 3 June, the southwesterly flow near the surface converges with the westerly flow in the frontal zone over the northeastern Taiwan Strait (Fig. 18b). However, without orographic effects, the barrier jet in the CR run (Fig. 16a) is not simulated in the NT run (Fig. 16b) and the amount of simulated vertically integrated grid-scale rainwater over the northern Taiwan Strait and northwestern Taiwan coast (Fig. 18b) is much lower than the CR run (Fig. 13c). Furthermore, the simulated surface front moves faster in the NT run than the CR run. For the NT run,
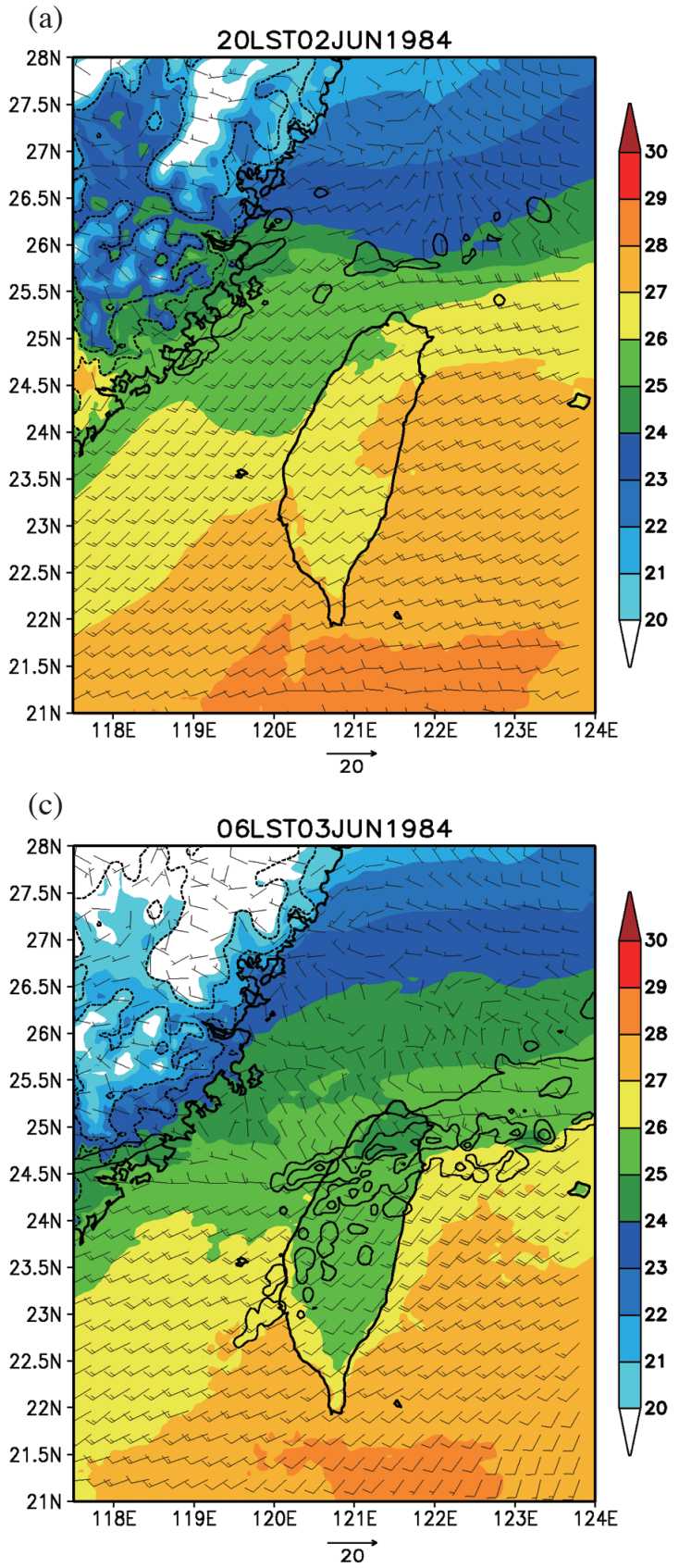

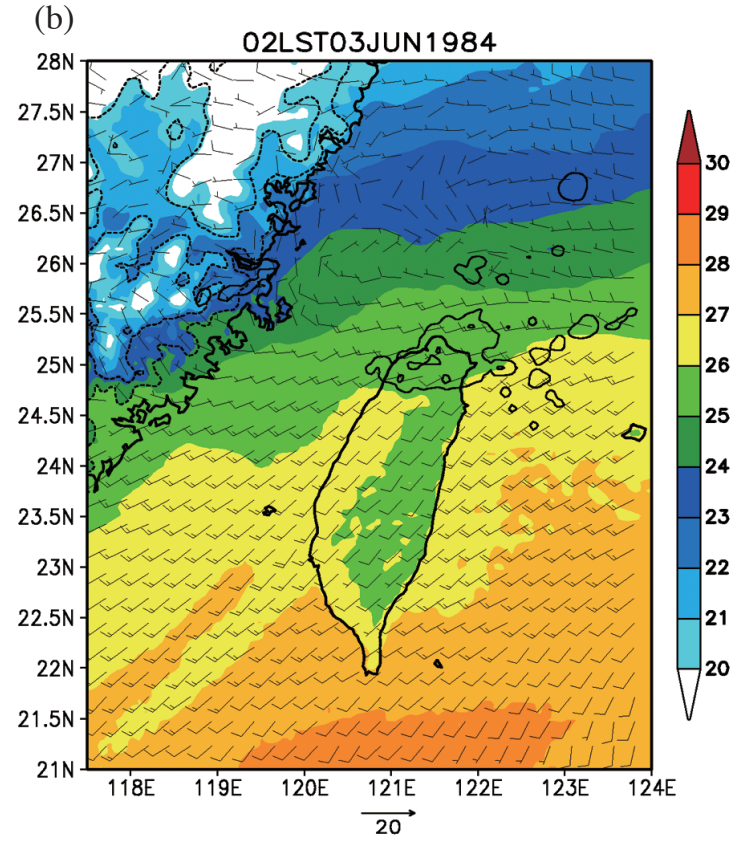

Fig. 18. (a) Same as Fig. 13a but for the NT run. (b) Same as (a) but at 02 LST 3 June. (c) Same as (a) but at 06 LST 3 June. 
at 06 LST the surface front and the associated rainfall system arrive over northern/central Taiwan (Fig. 18c) whereas the simulated surface front in the CR run just reaches the northwest coast of Taiwan (Fig. 13e).

\subsubsection{The Cold Pool from Convection}

It is well known that the interaction between the cold pool of convective cells and the environmental flow can enhance convection (Kerns et al. 2010; Markowsla and Rich- ardson 2010). At 20 LST 2 June, when the simulated precipitation system is still over the southeastern coast of China (Fig. 13a), southerly winds with relatively high temperature are simulated over the northeastern Taiwan Strait and the northwestern coast of Taiwan with a $3-\mathrm{km}$ grid domain (Fig. 19a). After the arrival of the simulated precipitation system (Figs. 13c and d), the outflow off the northwestern coast of Taiwan is clearly evident (Figs. 19b and c). Enhanced low-level convergence occurs over the southern boundary where the deflected southerly flow by the island (a)

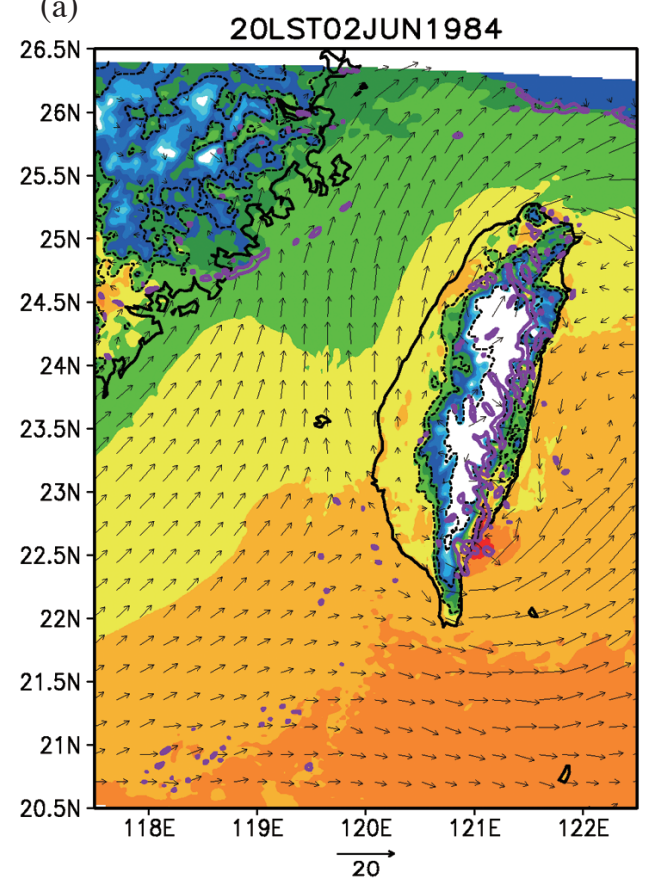

(c)

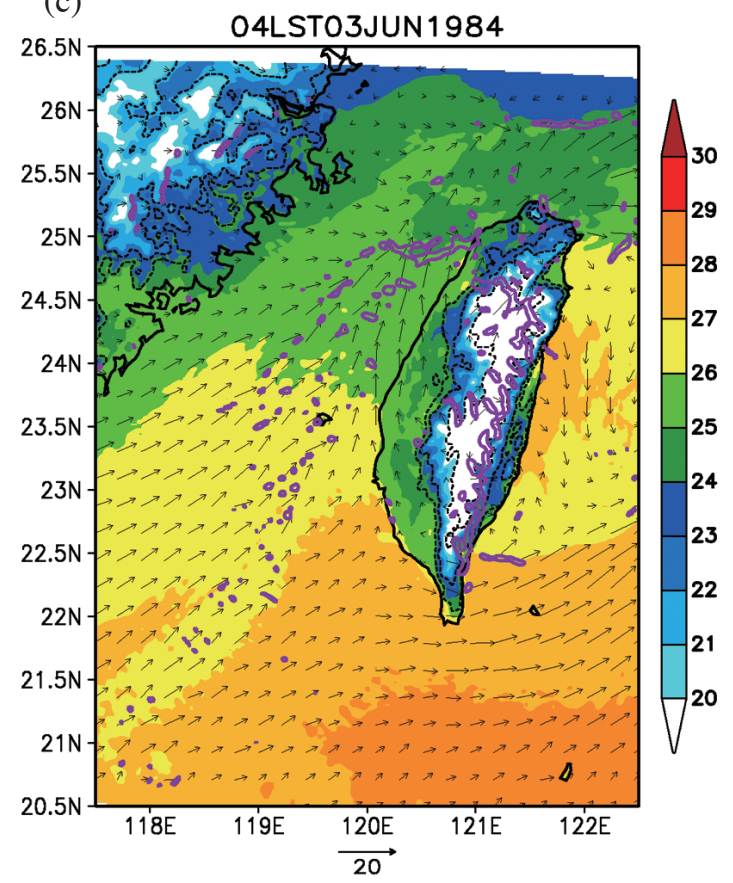

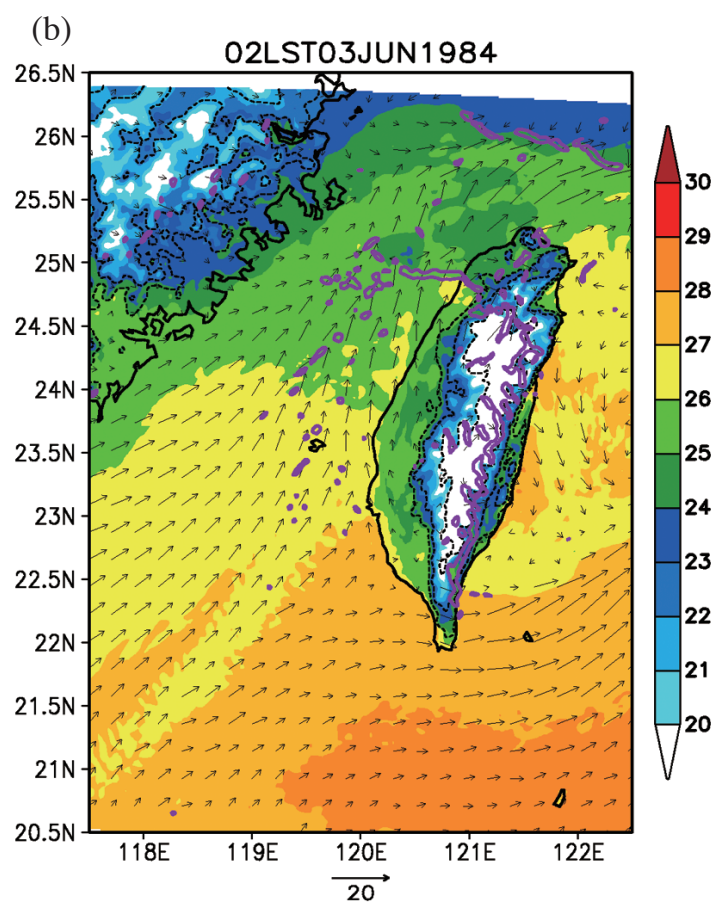

Fig. 19. (a) Simulated surface winds and temperature (every $1^{\circ} \mathrm{C}$ in gray scale) for 20 LST 2 June for the $3-\mathrm{km}$ grid domain of the control run. Terrain contours (dotted lines) are 200, 500 and $1500 \mathrm{~m}$, respectively. The areas with surface convergence exceeding $1 \times 10^{-3} \mathrm{~s}^{-1}$ are shaded in purple. The wind speed $\left(\mathrm{m} \mathrm{s}^{-1}\right)$ is specified at the bottom of the figure. (b) Same as (a) but for 02 LST 3 June. (c) Same as (a) but for 04 LST 3 June. 
topography converges with the outflow. High radar reflectivities (Figs. 14c and d) are present over the enhanced lowlevel convergence area. Thus, the role of the cold pool on the enhancement of localized heavy rainfall, suggested by Chiou and Liu (1985a), is successfully simulated using our convection-allowing models with a $3-\mathrm{km}$ resolution.

\subsubsection{Rainfall Simulation from the Nested 1-km Grid Domain}

The simulated accumulated daily rainfall over the northwestern coast from the $1-\mathrm{km}$ grid domain is over 400 $\mathrm{mm}$ and exceeds $200 \mathrm{~mm}$ over the Taipei Basin (Fig. 20a), about $50 \mathrm{~mm}$ less than the observed values (Fig. 10c). More than $250 \mathrm{~mm}$ of accumulated rainfall is simulated over the slopes south of the Taipei Basin, which is approximately $30 \mathrm{~mm}$ less than the observed values. The simulated rainfall pattern in northern Taiwan is oriented in a northeastsouthwest direction (Fig. 20a), consistent with the observed rainfall pattern (Fig. 10c). Without the presence of terrain in the model, the simulated daily rainfall accumulation in the $1-\mathrm{km}$ grid domain in the NT run on 3 June (Fig. 20b) is about $350 \mathrm{~mm}$ lower than in the CR run with a $1-\mathrm{km}$ grid domain (Fig. 20a). In the absence of orographic lifting over the southern Taipei Basin, the simulated rainfall accumulation within the Taipei Basin is only $40 \mathrm{~mm}$. These results suggest that under favorable large-scale settings, the localized offshore convergence zone and orographic lifting are essential for the occurrence of localized heavy rainfall.

(a)

00 23LST03JUN1984

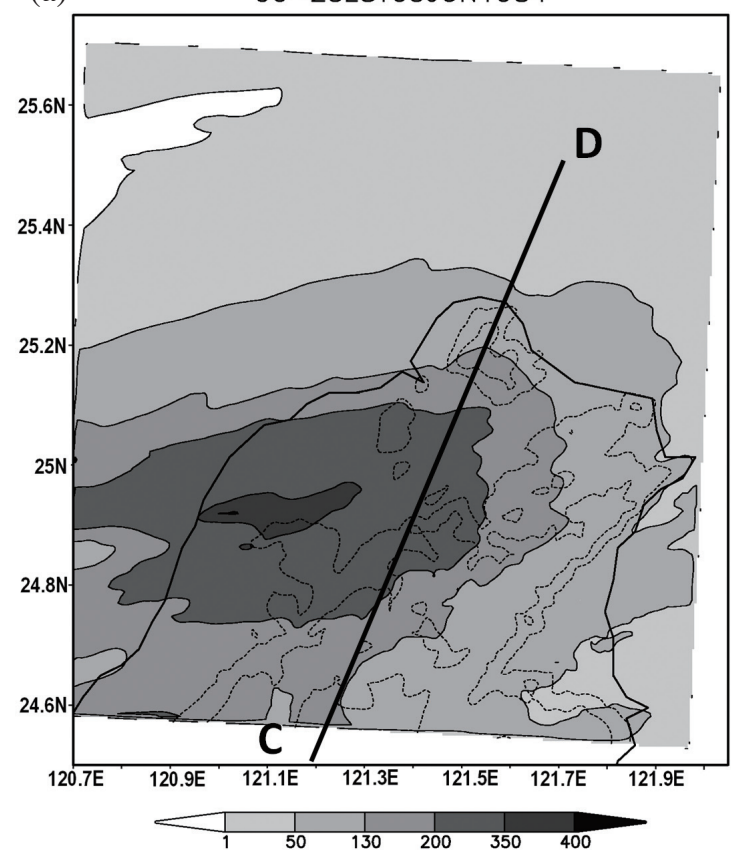

\section{CONCLUSION}

We investigate the mechanisms for the initiation and maintenance of a localized heavy rainfall event over northern Taiwan on 3 June 1984 by analyzing ECMWF data, satellite images, radar reflectivities, and WRF model simulations. The analysis of the ECMWF data indicates that upper-level divergence, low-level maximum equivalent potential temperature, low LFC, and subsynoptic ascending motion were present over the northern Taiwan Strait and northern Taiwan from the evening of 2 June to the early morning of 3 June. The nested WRF model with 27, 9, 3, and $1 \mathrm{~km}$ horizontal grids is used to simulate the occurrence of heavy rainfall over the northwestern Taiwan coast and within the Taipei Basin.

The observation and simulation results suggest that the occurrences of heavy rainfall in northern Taiwan can be classified into four stages. In stage I, at 20 LST 2 June, the preexisting rainfall system is simulated ahead of the windshift line associated with the low-level trough off the southeastern China coast as well as in the frontal area north of Taiwan and under favorable large-scale conditions that includes upperlevel divergence, low-level high equivalent potential temperature, low level of free convection (LFC), and subsynopticscale ascending motion over the northern Taiwan Strait. In stage II, during 23 LST 2 June - 02 LST 3 June, the simulated pre-existing precipitation areas over the southeastern China coast and north of Taiwan move southeastward. The convective rainfall is enhanced in the northern Taiwan Strait by orographic blocking where the prevailing southwesterly

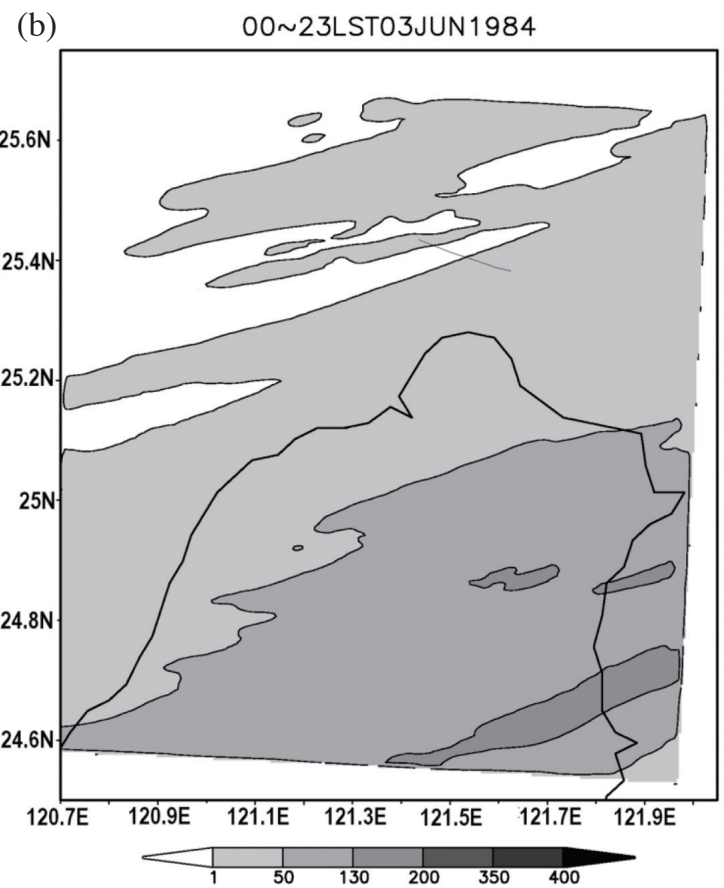

Fig. 20. (a) Simulated daily rainfall accumulation (grayscale in $\mathrm{mm}$ ) for 3 June from the 1-km grid domain. Terrain contours (dotted lines) are 200, 500 , and $1500 \mathrm{~m}$, respectively. (b) Same as (a) but for the NT run. 
wind within the Taiwan Strait converges with the orographically deflected flow with a southerly wind component off the western/northwestern Taiwan coast.

In stage III, from 02 to 06 LST 3 June, the surface front moves inland. Concurrently, the simulated rainfall commences over the northwestern coast and the Taipei Basin in agreement with the observations. As the simulated convective area continues to move toward northern Taiwan, it is enhanced in a localized low-level convergence area over the northwestern coast of Taiwan where a barrier jet along the coast converges with the northwesterly/westerly winds behind the surface front. Furthermore, the simulated rainfall system is enhanced where the barrier jet encounters the leading edge of the cold pool caused by rain evaporative cooling. In stage IV, after 06 LST 3 June, the low-level windshift line associated with the low-level trough axis reaches northern Taiwan with the heaviest rainfall over the northwestern coast and the Taipei Basin. In addition, as the convective systems drift inland, orographic lifting of the pre-frontal southwesterly flow helps to produce an increase in the simulated rainfall amount on the slopes south of the Taipei Basin. The heavy rainfall over northern Taiwan diminishes rapidly after the passage of the low-level trough axis.

Acknowledgments This work is supported by the National Science Council of the Republic of China under Grant NSC 100-2111-M-008-002. Dr. Yi-Leng Chen is funded by the National Science Foundation under Grant AGS-1142558.

We would like to thank the Central Weather Bureau, Taipei, Taiwan, and the Data Center of the Institute of Atmospheric Physics, National Central University, Chung-Li, Taiwan, for providing us with data. We would also like to thank reviewers for their helpful comments and May Izumi for editing the text. The computer resources were supplied by the Center for Computational Geophysics, National Central University.

This manuscript is dedicated to Dr. Chiou, former director of the Meteorological Satellite Center of the Central Weather Bureau. Dr. Chiou served as a director of the operation center for TiMREX during the 2008 early summer rainy (Mei-Yu) season and then suddenly passed away that same summer.

\section{REFERENCES}

Chen, C. S. and Y. L. Chen, 2003: The rainfall characteristics of Taiwan. Mon. Weather Rev., 131, 1323-1341, doi: 10.1175/1520-0493(2003)131<1323:TRCOT>2.0 .CO;2. [Link]

Chen, C. S., W. C. Chen, Y. L. Chen, P. L. Lin, and H. C. Lai, 2005: Investigation of orographic effects on two heavy rainfall events over southwestern Taiwan during the Mei-yu season. Atmos. Res., 73, 101-130, doi: 10.1016/j.atmosres.2004.07.005. [Link]

Chen, C. S., Y. L. Chen, C. L. Liu, P. L. Lin, and W. C.
Chen, 2007a: Statistics of heavy rainfall occurrences in Taiwan. Weather Forecast., 22, 981-1002, doi: 10.1175/WAF1033.1. [Link]

Chen, C. S., C. H. Lu, and W. C. Chen, 2007b: Numerical experiments investigating the mechanisms of a heavy rainfall event over northeastern Taiwan and a mesovortex during TAMEX. Meteorol. Atmos. Phys., 95, 155-177, doi: 10.1007/s00703-006-0201-z. [Link]

Chen, C. S., Y. L. Lin, W. C. Peng, and C. L. Liu, 2010a: Investigation of a heavy rainfall event over southwestern Taiwan associated with a subsynoptic cyclone during the 2003 Mei-Yu season. Atmos. Res., 95, 235-254, doi: 10.1016/j.atmosres.2009.10.003. [Link]

Chen, C. S., C. L. Liu, M. C. Yen, C. Y. Chen, P. L. Lin, C. Y. Huang, and J. H. Teng, 2010b: Terrain effects on an afternoon heavy rainfall event, observed over northern Taiwan on 20 June 2000 during monsoon break. J. Meteorol. Soc.Jpn., 88, 649-671, doi: 10.2151/jmsj.2010403. [Link]

Chen, C. S., Y. L. Lin, N. N. Hsu, C. L. Liu, and C. Y. Chen, 2011: Orographic effects on localized heavy rainfall events over southwestern Taiwan on 27 and 28 June 2008 during the post-Mei-Yu period. Atmos. Res., 101, 595-610, doi: 10.1016/j.atmosres.2011.04.004. [Link]

Chen, G. T. J, 1994: On the heavy rainfall research in the Taiwan Mei-Yu season. Atmos. Sciences., 22, 455-477. (in Chinese with English abstract)

Chen, Y. L., 1993: Some synoptic-scale aspects of the surface fronts over southern China during TAMEX. Mon. Weather Rev., 121, 50-64, doi: 10.1175/1520-0493(19 93) $121<0050:$ SSSAOT>2.0.CO;2. [Link]

Chen, Y.L., 2000: Effects of island airflow on rainfall distributions during the Mei-Yu season over Taiwan. Proc. Workshop on Numerical Simulations of Precipitation in Taiwan Area, National Central University, Taiwan, Chung-Li, 5-11.

Chen, Y. L. and N. B. F. Hui, 1990: Analysis of a shallow front during the Taiwan area mesoscale experiment. Mon. Weather Rev., 118, 2649-2667, doi: 10.1175/152 0-0493(1990)118<2649:AOASFD>2.0.CO;2. [Link]

Chen, Y. L. and N. B. F. Hui, 1992: Analysis of a relatively dry front during the Taiwan area mesoscale experiment. Mon. Weather Rev., 120, 2442-2468, doi: 10.1175/152 0-0493(1992)120<2442:AOARDF>2.0.CO;2. [Link]

Chen, Y. L. and J. Li., 1995a: Large-scale conditions favorable for the development of heavy rainfall during TAMEX IOP 3. Mon. Weather Rev., 123, 2978-3002, doi: 10.1175/1520-0493(1995)123<2978:LSCFFT>2. $0 . \mathrm{CO} ; 2$. [Link]

Chen, Y. L. and J. Li., 1995b: Characteristics of surface airflow and pressure patterns over the island of Taiwan during TAMEX. Mon. Weather Rev., 123, 695-716, doi: 10.1175/1520-0493(1995)123<0695:COSAAP >2 .0.CO;2. [Link] 
Chen, Y. L., X. A. Chen, and Y. X. Zhang, 1994: A diagnostic study of the low-level jet during TAMEX IOP 5. Mon. Weather Rev., 122, 2257-2284, doi: 10.1175/152 0-0493(1994)122<2257:ADSOTL>2.0.CO;2. [Link]

Chiou, T. K. and F. C. Liu, 1985a: A mesoscale analysis of heavy rainfall on June 3, 1984 and the discussion of flash floods in northern Taiwan. Meteorol. Bull., 31, 1-14. (in Chinese with English abstract)

Chiou, T. K. and F. C. Liu, 1985b: A case study of heavy rainfall in northern Taiwan on June 3, 1984. Atmos. Sciences., 12, 93-102. (in Chinese with English abstract)

Dudhia, J., 1996: A multi-layer soil temperature model for MM5. Preprints, Sixth PSU/NCAR Mesoscale Model Users' Workshop, Boulder, CO, 49-50. Available at http://www.mmm.ucar.edu/mm5/mm5v2/whatisnewinv2.html.

Holton, J. R., 2004: An Introduction to Dynamic Meteorology, Elsevier Academic Press, New York, 535 pp.

Janjić,Z. I., 1996: The surface layer in the NCEP Eta model. Preprints, Eleventh Conference on Numerical Weather Prediction, Norfolk, VA, 19-23 August, Amer. Meteor. Soc., Boston, MA, 354-355.

Janjić, Z. I., 2002: Nonsingular implementation of the Mellor-Yamada Level 2.5 scheme in the NCEP Meso model. National Centers for Environmental Prediction, Office Note \#437, $61 \mathrm{pp}$.

Kain, J. S . and J. M. Fritsch, 1993: Convective parameterization for mesoscale models: The Kain-Fritsch scheme. Meteorol. Monogr., 24, 165-170.

Kerns, B. W. J., Y. L. Chen, and M. Y. Chang, 2010: The diurnal cycle of winds, rain, and clouds over Taiwan during the Mei-Yu, summer, and autumn rainfall regimes. Mon. Weather Rev., 138, 497-516, doi: 10.1175/2009MWR3031.1. [Link]

Kuo, Y. H. and G. T. J. Chen, 1990: The Taiwan area mesoscale experiment (TAMEX): An overview. Bull. Amer. Meteorol. Soc., 71, 488-503, doi: 10.1175/15200477(1990)071<0488:TTAMEA>2.0.CO;2. [Link]

Li, J. and Y. L. Chen, 1998: Barrier jets during TAMEX. Mon. Weather Rev., 126, 959-971, doi: 10.1175/15200493(1998)126<0959:BJDT>2.0.CO;2. [Link]

Li, J., Y. L. Chen, and W. C. Lee, 1997: Analysis of a heavy rainfall event during TAMEX. Mon. Weather Rev., 125, 1060-1082, doi: 10.1175/1520-0493(1997)125<1 060:AOAHRE > 2.0.CO;2. [Link]

Lin, P. L., Y. L. Chen, C. S. Chen, C. L. Liu, and C. Y. Chen, 2011: Numerical experiments investigating the orographic effects on a heavy rainfall event over the northwestern coast of Taiwan during TAMEX IOP 13. Meteorol. Atmos. Phys., 114, 35-50, doi: 10.1007/ s00703-011-0155-7. [Link]

Lin, Y. L., 2007: Mesoscale Dynamics, Cambridge University Press, New York, 630 pp.

Markowski, P. and Y. Richardson, 2010: Mesoscale Meteorology in Midlatitudes, Wiley-Blackwell, West Sussex, UK, 407 pp.

Miller, J. E., 1948: On the concept of frontogenesis. J. Meteorol., 5, 169-171, doi: 10.1175/1520-0469(1948)005 $<0169$ :OTCOF>2.0.CO;2. [Link]

Skamarock, W. C., J. B. Klemp, J. Dudhia, D. O. Gill, D. M. Barker, W. Wang, and J. G. Powers, 2005: A description of the advanced research WRF version 2. NCAR Technical Note, NCAR/TN-468+STR, Mesoscale and Microscale Meteorology Division, National Center for Atmospheric Research, Boulder, Colorado, USA, $88 \mathrm{pp}$.

Sun, W. Y., J. D. Chern, C. C. Wu, and W. R. Hsu, 1991: Numerical simulation of mesoscale circulation in Taiwan and surrounding area. Mon. Weather Rev., 119, 2558-2573, doi: 10.1175/1520-0493(1991)119<2558: NSOMCI>2.0.CO;2. [Link]

Tao, W. K., J. Simpson, D. Baker, S. Braun, M. D. Chou, B. Ferrier, D. Johnson, A. Khain, S. Lang, B. Lynn, C. L. Shie, D. Starr, C. H. Sui, Y. Wang, and P. Wetzel, 2003: Microphysics, radiation and surface processes in the Goddard Cumulus Ensemble (GCE) model. Meteorol. Atmos. Phys., 82, 97-137.

Trenberth, K. E., 1978: On the interpretation of the diagnostic quasi-geostrophic omega equation. Mon. Weather Rev., 106, 131-137, doi: 10.1175/1520-0493(1978)10 6<0131:OTIOTD > 2.0.CO;2. [Link]

Wang, C. C., G. T. J. Chen, T. C. Chen, and K. Tsuboki, 2005: A numerical study on the effects of Taiwan topography on a convective line during the Mei-Yu season. Mon. Weather Rev., 133, 3217-3242, doi: 10.1175/ MWR3028.1. [Link]

Wang, S. T., H. Cheng, C. H. Shu, and Y. K. Chao, 1985: The environmental condition for heavy rainfall in Taiwan during May and June. Proc. Conf. on Weather Analysis and Forecasting, Central Weather Bureau, Taipei, Taiwan, 55-88.

Yeh, H. C. and Y. L. Chen, 2002: The role of offshore convergence on coastal rainfall during TAMEX IOP 3. Mon. Weather Rev., 130, 2709-2730, doi: 10.1175/152 0-0493(2002)130<2709:TROOCO > 2.0.CO;2. [Link]

Yeh, H. C. and Y. L. Chen, 2003: Numerical simulations of the barrier jet over northwestern Taiwan during the Mei-Yu season. Mon. Weather Rev., 131, 1396-1407, doi: 10.1175/1520-0493(2003)131<1396:NSOTBJ>2 . 0.CO;2. [Link] 